\title{
The impact of dust storms on the Arabian Peninsula and the Red Sea
}

\author{
P. Jish Prakash, G. Stenchikov, S. Kalenderski, S. Osipov, and H. Bangalath \\ Division of Physical Sciences and Engineering, King Abdullah University of Science and \\ Technology, Thuwal, Saudi Arabia \\ Correspondence to: G. Stenchikov (georgiy.stenchikov@kaust.edu.sa) \\ Received: 24 February 2014 - Published in Atmos. Chem. Phys. Discuss.: 22 July 2014 \\ Revised: 3 November 2014 - Accepted: 26 November 2014 - Published: 12 January 2015
}

\begin{abstract}
Located in the dust belt, the Arabian Peninsula is a major source of atmospheric dust. Frequent dust outbreaks and some 15 to 20 dust storms per year have profound effects on all aspects of human activity and natural processes in this region. To quantify the effect of severe dust events on radiation fluxes and regional climate characteristics, we simulated the storm that occurred from 18 to 20 March 2012 using a regional weather research forecast model fully coupled with the chemistry/aerosol module (WRF-Chem). This storm swept over a remarkably large area affecting the entire Middle East, northeastern Africa, Afghanistan, and Pakistan. It was caused by a southward propagating cold front, and the associated winds activated the dust production in river valleys of the lower Tigris and Euphrates in Iraq; the coastal areas in Kuwait, Iran, and the United Arab Emirates; the Rub al Khali, An Nafud, and Ad Dahna deserts; and along the Red Sea coast on the west side of the Arabian Peninsula. Our simulation results compare well with available ground-based and satellite observations. We estimate the total amount of dust generated by the storm to have reached $94 \mathrm{Mt}$. Approximately $78 \%$ of this dust was deposited within the calculation domain. The Arabian Sea and Persian Gulf received 5.3 Mt and the Red Sea 1.2 Mt of dust. Dust particles bring nutrients to marine ecosystems, which is especially important for the oligotrophic Northern Red Sea. However, their contribution to the nutrient balance in the Red Sea remains largely unknown. By scaling the effect of one storm to the number of dust storms observed annually over the Red Sea, we estimate the annual dust deposition to the Red Sea, associated with major dust storms, to be $6 \mathrm{Mt}$.
\end{abstract}

\section{Introduction}

Mineral dust is the dominant atmospheric aerosol (Buseck and Posfai, 1999). It plays an important role in the Earth's climate system, although the magnitude and even the sign of its radiative effect at the top of the atmosphere (TOA) remain uncertain. Most airborne dust is generated in desert and semidesert areas and transported across local to global scales.

Dust storms lift millions of tons of dust into the atmospheric boundary layer. Such large quantities of dust cause severe air pollution, reduced visibility, airport shutdowns, and increased traffic and aircraft accidents (Morales, 1979; Hagen and Woodruff, 1973; Middleton and Chaudhary, 1988; Dayan et al., 1991; Chung and Yoon, 1996). Other environmental impacts of dust include reduced soil fertility and crop damage, reduced solar radiation on the surface and as a consequence decreased efficiency of solar devices, damaged telecommunications and mechanical systems, increased occurrence of respiratory diseases, and other impacts on human health (Hagen and Woodruff, 1973; Mitchell, 1971; Fryrear, 1981; Squires, 2007; Jauregui, 1989; Liu and Ou, 1990; Chung and Yoon, 1996; Nihlen and Lund, 1995; Longstreth et al., 1995; Bennett et al., 2006; Bennion et al., 2007). Dust deposition to oceans, however, provides nutrients to ocean surface waters and the seabed (Talbot et al., 1986; Swap et al., 1996 and Zhu et al., 1997).

The direct and indirect atmospheric radiative impact of dust has implications in global climate change and presently is one of the largest unknowns in climate model predictions. The African and Asian low-latitude deserts, the so-called dust belt, are the major sources of dust for the entire world (Pye, 1987; Prospero et al., 1987, Arimoto et al., 1989; Laurent et al., 2008; Uno et al., 2005). The dust belt includes 
the Sahara, arid and semiarid regions in Arabia and Central Asia, and the Taklamakan desert and Gobi in East Asia. During severe dust storms, dust from East Asia can reach far beyond the continent, drifting over the Pacific Ocean to the west coast of North America (Husar et al., 2001; Tratt et al., 2001; Mc Kendry et al., 2001). Similarly, Saharan dust crosses the Atlantic and affects both Americas (Prospero et al., 1987; Reid and Maring, 2003; Haywood et al., 2003).

The Sahara is the world's largest dust source (Washington et al., 2003; Shao et al., 2011). The characteristics of Saharan dust were studied experimentally since the 1990s (Jayaraman et al., 1998; Satheesh and Ramanathan, 2000; Haywood and Boucher, 2000). The Puerto Rico dust experiment (PRIDE) (Reid and Maring, 2003) and the Saharan dust experiment (SHADE) (Haywood et al., 2003) focused on Saharan dust during long-range transport. Two comprehensive field campaigns were conducted in 2006 (Heintzenberg, 2009) and 2008 (Ansmann et al., 2011) under the framework of the Saharan mineral dust experiment (SAMUM) to quantify the optical properties and the radiative impact of Saharan dust near source regions and in the aged mixed plume from Saharan dust and biomass burning aerosols transported west off the African continent. The Fennec 2011 campaign (Washington et al., 2012) made significant advances by providing new measurements close to dust sources over the remote Sahara.

It has long been recognized that radiative effects of mineral aerosols are an important driver of the climate (Tegen and Fung 1994, 1995; Tegen et al. 1996; Lie et al., 1996; Andreas, 1996). Early attempts at dust modeling using global models were made by Westphal et al. (1987, 1988), Gillette and Hanson (1989), Joussaume (1990), and Tegen and Fung (1994, 1995). The presence of dust affects atmospheric heating rates and thus atmospheric stability and circulation, which together with changes in the surface energy balance affect the hydrologic cycle (Miller and Tegen, 1998; Miller et al., 2004b).

Miller and Tegen (1998) conducted one of the first studies of the radiative effects of dust using a global general circulation model (GCM) coupled with a mixed ocean module to show that dust aerosols reduce the global average surface net radiation by nearly $3 \mathrm{~W} \mathrm{~m}^{-2}$ during summer in the northern hemisphere. Tegen et al. (1996) showed that dust from disturbed soils causes a decrease in the net surface radiation by about $1 \mathrm{~W} \mathrm{~m}^{-2}$. Recently, Balkanski et al. (2007) confirmed that the global average dust-related surface net radiative flux change is in the range of -1.11 to $0.92 \mathrm{~W} \mathrm{~m}^{-2}$. However, the radiative effect of dust in desert regions during dust outbreaks could be 2 orders of magnitude stronger (Kalenderski et al., 2013). A comprehensive analysis of simulated global dust distributions and their radiative effects was recently conducted under the scope of the aerosol intercomparison (AeroCom) project (Textor et al., 2006; Stier et al., 2007).

Regional-scale dust effects were addressed using fineresolution limited area models (e.g., Nickovic et al., 2001; Uno et al., 2001; Lu and Shao, 2001; Kaskaoutis et al., 2008;
Tegen et al., 2013). A regional modeling system was developed for simulations of Saharan dust emissions, transport, and radiative effects (Heinold et al., 2008, 2009; Laurent et al., 2010; Tegen et al., 2010) during SAMUM-1. A regional model was also used to simulate the spatiotemporal evolution of the mixed plume of Saharan dust and biomass burning aerosols (Heinold et al., 2011a), the radiative effect, and the dynamic response of the atmosphere due to Saharan dust and biomass burning (Heinold et al., 2011b) during SAMUM-2.

The studies mentioned thus far mostly focused on western and central North Africa, the Sahel, and Sahara regions. There are relatively fewer measurement and modeling studies focusing on eastern North Africa and the Arabian Peninsula. This region has been severely under-sampled; there are few available in situ observations, and very few international research campaigns have been conducted in this area compared to the Sahara. In the Arabian Peninsula, dust storms and blowing dust are frequent events throughout most of the year. The major dust sources in the Arabian Peninsula include the Tigris and Euphrates River Valleys, the alluvial plain in Iraq and Kuwait, the low-lying flat lands in the east of the peninsula along the Persian Gulf, and the Ad Dahna and the Rub Al Khali deserts (Kutiel and Furman, 2003; Shao, 2008). Goudie and Middleton (2006) provided an extensive discussion of the causes of dust storms in the Middle East. Eastern Syria, northern Jordan, and western Iraq are the source for most of the fine dust particles (less than $50 \mu \mathrm{m}$ in diameter) found in Arabian dust storms (NOAA, 2002). This dust is transported far into southern Arabia where it may have contributed to loess deposits on parts of the Arabian Shield and even in the Asir Plateau. Sandstorms containing larger particles (150 to $300 \mu \mathrm{m}$ in diameter) are also frequent throughout Arabia but rarely reach above $15 \mathrm{~m}$ altitude. Most sand grains move by saltation and some by surface creep; they rarely move in suspension by storm winds, haboobs, or dust devils.

Dust storms in the southern Arabian Peninsula are more frequent in summer. In the northern Arabian Peninsula they occur mainly in spring. The peak of dust storm activity occurs usually during the daytime, when intense solar heating of the ground generates turbulence and local pressure gradients (Middleton, 1986a, b). Across the Arabian Peninsula, dust activity peaks from May to August (Prospero et al., 2002; Washington et al., 2003; Barkan et al., 2004; Goudie and Middleton, 2006). The United Arab Emirates unified aerosol experiment $\left(\mathrm{UAE}^{2}\right)$ focused on dust in the coastal and desert regions of the United Arab Emirates in August to September 2004 to evaluate the properties of dust particles that converge in the UAE region from numerous sources and their impact on the radiation budget (Reid et al., 2008). Mohalfi et al. (1998) studied the effect of dust aerosols on the synoptic system and showed that dust aerosol radiative heating strengthens Saudi Arabian heat low. Kalenderski et al. (2013) simulated a winter dust event that occurred in January 2009 over the Arabian Peninsula and the Red Sea to 
study various dust phenomena. Notaro et al. (2013) investigated the temporal and spatial characteristics of Saudi Arabian dust storms using trajectory analysis. Using MODIS data, they found that the highest aerosol optical depth (AOD) is achieved during dust storms that originate from the $\mathrm{Rub} \mathrm{Al}$ Khali and Iraqi Deserts.

This study aims to quantify the impact of dust on the Arabian Peninsula and Red Sea, focusing on the severe dust storm observed from 18 to 22 March 2012. This storm likely drew at least some of its dust from Iraq, Iran, Kuwait, and the Arabian Peninsula Rub' al Khali desert (Empty Quarter), sprawling over parts of Saudi Arabia, Yemen, Oman, and UAE. The simulation period was from 00:00 UTC (Universal Time Coordinate) on 5 March to 00:00 UTC on 25 March 2012 with the model spin-up during the first 6 days. Using model output and observations, we provide an improved estimate of the storm's impact on the terrestrial and oceanic environment.

The remainder of this paper is organized as follows. Section 2 discusses the model's configuration and methodology. Section 3 examines the environmental conditions that led to the development of the dust storm, estimates the dust emissions, load, and deposition, discusses the structure of the dust storm, compares model results with available Aerosol Robotic Network (AERONET) and satellite observations, presents the vertical structure of atmosphere and dust distribution, and calculates radiative effect of dust. We offer a summary of the results in Sect. 4.

\section{Methodology}

In this study, we combine advanced high-resolution modeling of meteorological and dust processes with analysis of ground-based and satellite observations of aerosols and meteorological fields.

\subsection{Modeling}

The Weather Research Forecast (WRF) system is a mesoscale forecast model with an incorporated data assimilation capability that advances both the understanding and prediction of weather (Skamarock et al., 2008). WRF has been utilized in a variety of research and operational projects, from the scale of convective storms to the scale of continental weather patterns (Michalakes et al., 2005). The chemistry/aerosol module (WRF-Chem) extends WRF by incorporating a chemistry module that interactively simulates emissions of aerosols and gases, their transport, turbulent and convective mixing, and chemical and microphysical transformations of trace gases and aerosols (Grell et al., 2005).

Here, we configured WRF-Chem with the regional acid deposition model 2 (RADM2) photochemical mechanism (Stockwell et al., 1990), the Fast-j photolysis scheme (Wild et al., 2000), the modal aerosol dynamics model for $\mathrm{Eu}-$ rope (MADE), and the secondary organic aerosol model (SORGAM) (Ackermann et al., 1998; Schell et al., 2001). We also employed the Goddard global ozone chemistry aerosol radiation and transport (GOCART) dust emission scheme (Ginoux et al., 2001) to calculate the influx of dust into the atmosphere. GOCART simulates dust emissions as a function of surface wind speed, surface erodibility, and surface wetness (Chin et al., 2002). Emission flux, $F_{p}$, for a specific aerosol size group, $p$, is expressed as

$F_{p}=C S s_{\mathrm{p}} U_{10 \mathrm{~m}}^{2}\left(U_{10 \mathrm{~m}}-U_{t}\right)$ if $U_{10 \mathrm{~m}}>U_{\mathrm{t}}$,

where $C$ is a dimensional constant coefficient of proportionality; $S$ is the space-dependent dimensionless erodibility field taken from Ginoux et al. (2001) with a spatial resolution of $0.25^{\circ} \times 0.25^{\circ} ; U_{10 \mathrm{~m}}$ is the wind speed $10 \mathrm{~m}$ above the ground; $U_{\mathrm{t}}$ is the threshold velocity of wind erosion, which depends on particle size and surface wetness; and $s_{\mathrm{p}}$ is a particular particle size mode mass fraction emitted in the atmosphere. The original GOCART emission scheme was coupled with the 8 bin aerosol model. However, in this study WRF-Chem is configured with the MADE/SORGAM that uses the modal approach with three log-normal distributed modes (aitken, accumulation, and coarse) to represent sulfate, nitrate, ammonium, organic matters, black carbon, and sea salt. Mineral dust is assumed to have only accumulation and coarse modes. The GOCART emission scheme has been modified to couple with the MADE/SORGAM. It calculates a dust mass flux from the surface (see Eq. 1) assuming that, by default, $s_{\mathrm{p}}=0.07$ for accumulation mode, which for emitted particles has the modal diameter $D=0.6 \mu \mathrm{m}$, width $\sigma=2 \mu \mathrm{m}$; and $s_{\mathrm{p}}=0.93$ - for coarse mode with $D=6 \mu \mathrm{m}$, $\sigma=2.2 \mu \mathrm{m}$. According to MADE/SORGAM formulation, the modal diameters change in the atmosphere due to microphysical processes but the widths of both distributions remain fixed. The total emission flux is adjusted using constant $\mathrm{C}$ in Eq. (1) to fit AERONET observations, as discussed by Zhao et al. (2010) and Kalenderski et al. (2013). In our simulations, we used $C=0.8 \mathrm{mg} \mathrm{s}^{2} \mathrm{~m}^{-5}$ to achieve consistency between the simulated and AERONET aerosol optical thickness (AOD) observed from 11 to 24 March 2012.

To cover the entire area affected by the storm and to account for processes that were responsible for the storm's development, we ran the WRF-Chem model in the spatial domain from $4^{\circ} \mathrm{N}$ to $40^{\circ} \mathrm{N}$ in longitude and $25^{\circ} \mathrm{E}$ to $80^{\circ} \mathrm{E}$ in latitude with $10 \mathrm{~km}$ horizontal resolution. In our calculations, we therefore used 495 grid points in the west-east direction and 396 grid points in the south-north direction, as well as 40 vertical levels with the top-of-the-model domain at the $10 \mathrm{hPa}$ level. The following physical parameterizations were used to configure the WRF-Chem simulations: the Lin microphysics scheme, the rapid radiative transfer model (RRTMG) for both long-wave (LW) and shortwave (SW) radiation, the Mellor-Yamada-Janjic (MYJ) boundary layer scheme, the Noah land surface model, and the Grell cumulus parameterization. Lateral boundary and initial condi- 
tions for meteorological fields were provided by the National Centers for Environmental Prediction (NCEP) global analysis (FNL). We used NCEP daily global sea surface temperature (SST) analysis (RTG_SST_HR) to update SST every $6 \mathrm{~h}$. The various model domain configurations and physics options are summarized in Table 1.

\subsection{Observations}

To test and constrain the model simulations, we used reanalysis fields as well as meteorological and aerosol observations available in the Middle East and surrounding areas.

\subsubsection{Space-borne aerosol instrumental observations}

Aerosol optical depth (AOD) data from MODIS sensors onboard the Terra and Aqua satellites are widely used in aerosol studies (Salomonson et al., 1989). The MODIS instrument provides high radiometric sensitivity (12 bit) in 36 spectral bands ranging in wavelength from $0.4 \mu \mathrm{m}$ to $14.4 \mu \mathrm{m}$. Two bands are imaged at a nominal resolution of $0.25 \mathrm{~km}$ at nadir, five bands at $0.50 \mathrm{~km}$, and the remaining 29 bands at $1 \mathrm{~km}$. A $\pm 55^{\circ}$ scanning pattern of the Earth Observing Satellite (EOS) orbit at $705 \mathrm{~km}$ altitude achieves a $2330 \mathrm{~km}$ swath and provides global coverage every 1 to 2 days. The MODIS daily Level-2 AOD data are produced at the spatial resolution of a $10 \mathrm{~km} \times 10 \mathrm{~km}$ (at nadir). There are two MODIS aerosol data products, one containing data collected from the Terra platform and the other containing data collected from the Aqua platform. To maximize the observation coverage, we used AOD retrievals over land and sea derived from the dark target product (Remer et al., 2005, 2008) and the "deep blue" product over bright land surfaces (Hsu et al., 2004, 2006). The dark target ocean and land AOD products were available from both Terra and Aqua, but the deep blue retrievals were only available from Aqua. In this study, we have used daily deep blue (Level 2) data in combination with the standard ocean algorithm for comparison with the simulated aerosol optical properties.

The Spinning Enhanced Visible Infrared Radiometer (SEVIRI) (Aminou et al., 2002) is a line scanning radiometer currently located on-board the European geostationary meteorological satellite, Meteosat-9; it was previously on Meteosat-8. This instrument provides data in four visible and near infrared channels and eight infrared channels with a resolution of $3 \mathrm{~km}$ at nadir. In this study we used the $0.6 \mu \mathrm{m}$ channel. An advantageous feature of SEVIRI is its ability to image the study area with high temporal resolution of $15 \mathrm{~min}$. This allows SEVIRI to track aerosol events, which offers a great advantage over polar orbiting instruments like MODIS that usually see the particular scene once a day. The SEVIRI's spatial resolution is, however, coarser than that of MODIS, but the aerosol gridded products for the Arabian Peninsula from both instruments are on the $10 \mathrm{~km} \times 10 \mathrm{~km}$ grid.

\subsubsection{Ground-based aerosol observations}

The Aerosol Robotic Network (AERONET) uses Cimel robotic sun photometers and provides observations of AOD on up to eight wavelength channels between 0.340 and $1.640 \mu \mathrm{m}$ (Holben et al., 1998) and angular distribution of sky radiance at four wavelengths $(0.440,0.675,0.870$, and $1.020 \mu \mathrm{m})$. In addition to the direct measurement of AOD, the inversion algorithm retrieves physical and optical properties of aerosols that comprise the aerosol refractive index, column average size distribution, single scattering albedo, and asymmetry parameter. The maximum AERONET uncertainty in AOD retrieval is estimated to be 0.02 with the highest error in the ultraviolet wavelength (Holben et al., 1998; Eck et al., 1999), and the calibrated sky radiance measurements typically have an uncertainty less than $5 \%$ (Holben et al., 1998). Cimel sun photometers are calibrated annually by comparison to an AERONET master instrument.

The AERONET data are at high time resolution but have limited spatial coverage. During the study period, AOD observations were available at Kuwait University $\left(29.32^{\circ} \mathrm{N}\right.$, $\left.47.97^{\circ} \mathrm{E}\right)$, at Mezaira $\left(23.14^{\circ} \mathrm{N}, 53.77^{\circ} \mathrm{E}\right)$, and at our own site established in February 2012 on the King Abdullah University of Science and Technology (KAUST) campus $\left(22.30^{\circ} \mathrm{N}, 39.10^{\circ} \mathrm{E}\right)$. We chose cloud-screened (Level 1.5) AERONET AOD for our model validation since Level-2 data (cloud-screened and quality-assured data) were not available during the simulation period. The Angstrom power law was used for comparing the simulated optical properties output at $0.60 \mu \mathrm{m}$ with the AERONET measurements as follows:

$$
\operatorname{AOD}(0.600)=\operatorname{AOD}(0.675) \times\left(\frac{0.600}{0.675}\right)^{-\alpha},
$$

where $\alpha$ is the Angstrom exponent calculated from the AERONET measurement as

$\alpha=\frac{\ln \left[\frac{\mathrm{AOD}(0.440)}{\mathrm{AOD}(0.675)}\right]}{\ln \left(\frac{0.675}{0.440}\right)}$.

\subsubsection{Weather station meteorological observations}

There are meteorological data from 108 surface weather stations and 12 upper air stations available in the area of interest. For the purposes of this study, we focus on the upper air radiosonde data. The radiosonde (RS) is a balloonborne instrument platform with radio transmitting capabilities. Data from the radiosonde are interpreted at the launching station and entered into a worldwide communications network. The time sampling of RS data is usually twice daily at 00:00 UTC (midnight) and 12:00 UTC (noon). RS profiles contain pressure, temperature, relative humidity, wind speed, and wind direction. Depending on the sensor and balloon used at each location, the vertical resolution of RS data typically has 40 levels between 1000 and $50 \mathrm{hPa}$. We used 
Table 1. Model setup parameters.

\begin{tabular}{ll}
\hline Model name & WRF-Chem (Grell et al.,2005) \\
\hline Horizontal resolution & $10 \mathrm{~km}$ \\
Dimensions $(X, Y)$ & 495,396 \\
Vertical levels & 40 \\
Boundary conditions & NCEP final analysis FNL \\
Time step & $60 \mathrm{~s}$ \\
Dust-radiative feedback & Yes \\
Simulation period & $11-24$ March 2012 \\
Physical schemes & Microphysics: Lin et al. Scheme (Lin et al., 1983) \\
& PBL: Mellor-Yamada-Janjic (MYJ) TKE scheme (Janjic, 2001) \\
& Surface: unified Noah land-surface model (Chen and Dudhia, 2001) \\
& Cumulus convection: new Grell scheme (Grell and Devvenyi, 2002) \\
Emission scheme & GOCART scheme (Ginoux et al., 2001) \\
Aerosol model & MADE/SORGAM (Ackerman et al., 1998; Schell et al., 2001) \\
Photolysis scheme & Fast-J (Wild et al., 2000) \\
Gas-phase mechanism & RADM2 (Stockwell et al., 1990) \\
Dust SW refractive index & 0.003 \\
\hline
\end{tabular}

observations from three RS stations for a comparison with model results. Stations are identified by their World Meteorological Organization (WMO) five digit codes. The three stations over the Arabian Peninsula selected for this study include Jeddah (41024), Abu Dhabi (41217), and Kuwait (40582). The vertical temperature RS profiles were retrieved from the upper air archive at the University of Wyoming (http://weather.uwyo.edu/upperair/sounding.html).

\subsubsection{Reanalysis output}

To compare meteorological fields and spatial patterns, we use output from the European Centre for Medium-Range Weather Forecast (ECMWF) ERA-Interim (ERA-I) reanalysis (Dee et al., 2011). It is the latest global atmospheric reanalysis produced by ECMWF as a transition between ERA40 and a future reanalysis project. It provides information on a large variety of surface parameters (3-hourly), describing weather as well as ocean-wave and land-surface conditions and 6-hourly upper-air parameters (37 pressure levels up to $1 \mathrm{hPa}$ ) on a $0.7^{\circ} \times 0.7^{\circ}$ grid. ERA-I uses an improved atmospheric model and a more sophisticated data assimilation method (4D-Var) for atmospheric analysis compared to ERA-40. Information about the current status of ERA-I production and availability of online data can be found at (http://apps.ecmwf.int/datasets/data/interim_full_daily/).

\section{Results}

The dust storm from 18 to 22 March 2012 covered an extremely large area and disrupted human activities in Iraq, Iran, Kuwait, Syria, Jordan, Israel, Lebanon, UAE, Qatar, Bahrain, Saudi Arabia, Oman, Yemen, Sudan, Egypt, Afghanistan, and Pakistan. Many airports in these countries were shut down because of dust impact on visibility and machinery.

\subsection{Meteorological conditions and storm spatial-temporal development}

Figure 1 shows geopotential height from WRF-Chem simulations and ERA-Interim reanalysis at $500 \mathrm{hPa}$ at 00:00 UTC from 17 to 19 March 2012. Sea-level pressure for the same days at 00:00 UTC is shown in Fig. 2. The model results compare well with the reanalysis fields in both figures. On 17 March there was a trough in the mid-troposphere at $500 \mathrm{hPa}$ stretching over the eastern Mediterranean Sea, Syria, Iraq, western Iran, and northern Saudi Arabia. This upper air disturbance caused a significant pressure decrease in the lower atmosphere and a low-pressure system consequently developed in eastern Iraq and northwestern Iran with a central sea-level pressure of $1008 \mathrm{hPa}$. A high pressure is seen over northeastern Afghanistan and Tajikistan. The spatial distribution of $10 \mathrm{~m}$ wind bars at 09:00 UTC from 17 to 19 March is shown in Fig. 3. Strong surface winds of $15 \mathrm{~m} \mathrm{~s}^{-1}$ are observed over northwestern Iraq on 17 March at 09:00 UTC (Fig. 3a).

On 18 March the high-level trough deepened and moved southeastward into the northern Arabian Peninsula covering Iraq and western Iran. A surface high pressure builds up over the eastern Mediterranean Sea. The presence of a low pressure in southern Saudi Arabia, the Gulf of Oman, and central Iran in combination with a high in the eastern Mediterranean Sea enhanced a strong pressure gradient along the Arabian Peninsula. As a result, a strong surface wind of $15 \mathrm{~m} \mathrm{~s}^{-1}$ developed to the west of the low near the Persian Gulf in southeastern Saudi Arabia and Qatar and to the northeast of UAE (Fig. 3b). This is well above the generally assumed threshold wind speed (5 to $6 \mathrm{~m} \mathrm{~s}^{-1}$ ) for dust sus- 

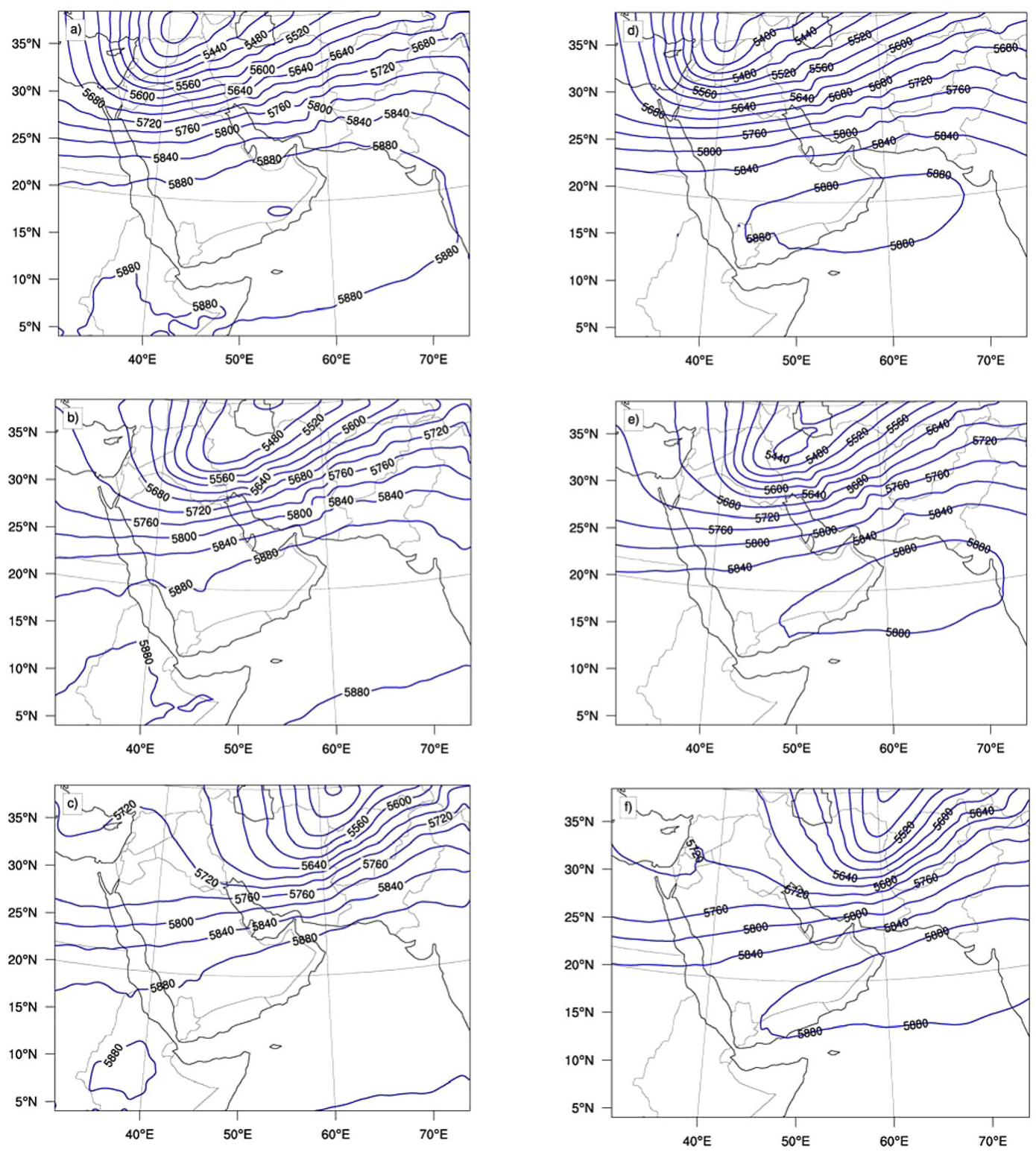

Figure 1. Geopotential height (m) at $500 \mathrm{hPa}$ at 00:00 UTC from WRF-Chem simulations on (a) $17 \mathrm{March}$, (b) $18 \mathrm{March}$, and (c) $19 \mathrm{March}$ 2012 and from ERA-Interim reanalysis on (d) 17 March, (e) 18 March, and (f) 19 March 2012.

pension (Gillette, 1978). These strong winds forced the dust emission and transported dust to the south and southwest of the Arabian Peninsula.

On 19 March the high-level trough moved towards eastern Iran and western Afghanistan. The low-pressure system in the southern Arabian Peninsula was overtaken by the highpressure system. A low-pressure system that developed in central Pakistan in combination with the high pressure in the northern Arabian Peninsula increased surface winds in southern Iran up to $20 \mathrm{~m} \mathrm{~s}^{-1}$ (Fig. 3c). One of the most identifiable synoptic features in the Arabian Peninsula during the simulation is the low-pressure system that moved southeastward through the Peninsula on 19 March 2012, suggest- ing that the dust storm was closely related to the south and southwestward propagation of a cold front. Figure 4 shows the simulated near-surface wind field and dust concentration at 08:00 UTC and 15:00 UTC on 18 March 2012. Comparisons with synoptic observations confirm that the flow field is well simulated. The cold front is a line-shaped narrow region stretching from the western coast of Saudi Arabia to eastern UAE, as can be seen from the dense temperature contours (Fig. 4a). Strong northeasterly wind (maximum $15 \mathrm{~m} \mathrm{~s}^{-1}$ ) prevailed behind the cold front, resulting in strong dust emissions and high dust concentrations. The dust was carried southwestward by the northeasterly wind to converge on the frontal area, resulting in high dust concentrations near 

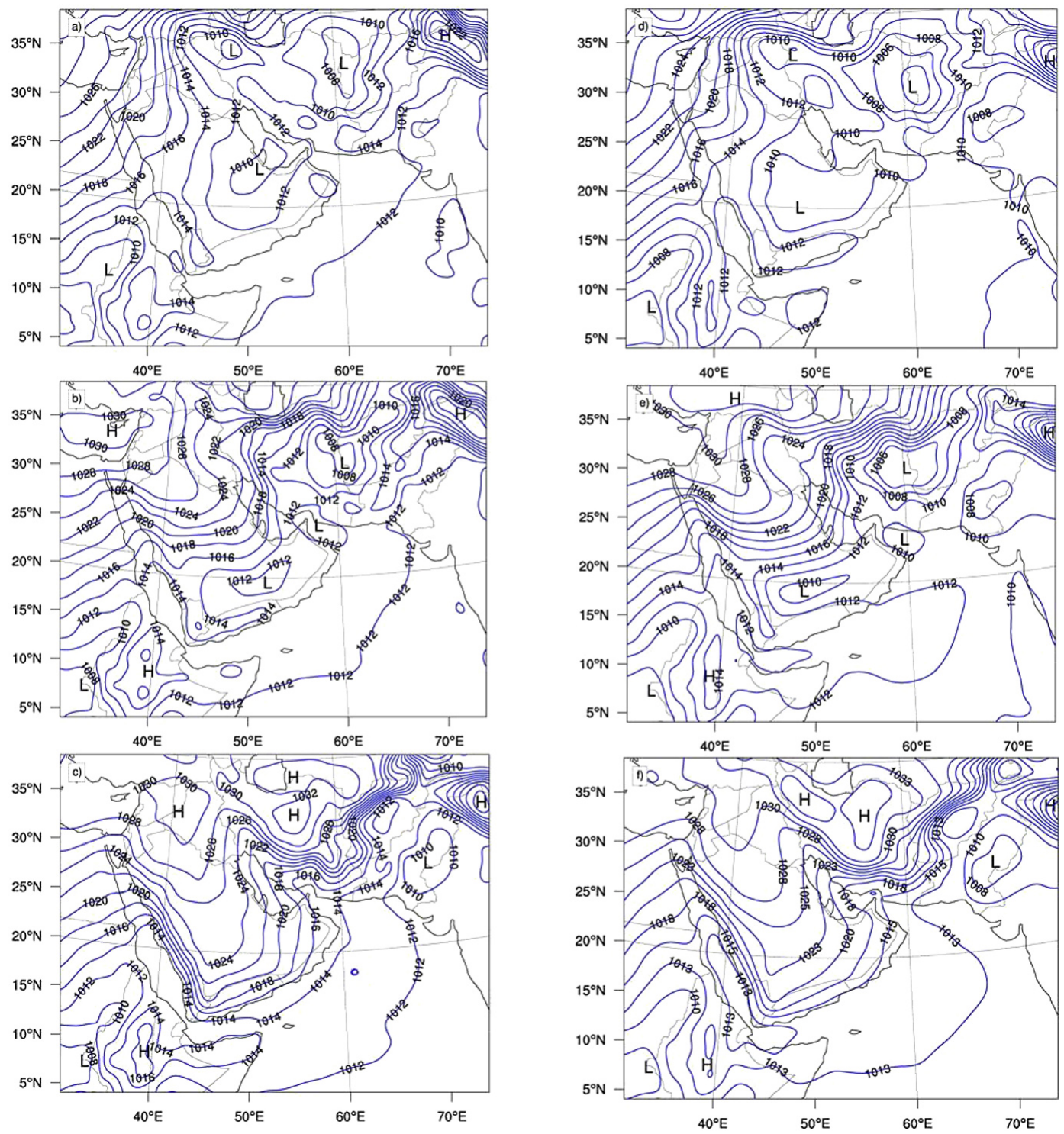

Figure 2. Sea-level pressure (hPa) with $\mathrm{H}$ and $\mathrm{L}$ markers indicating low and high pressure systems at 00:00 UTC from WRF-Chem simulations on (a) 17 March, (b) 18 March, and (c) 19 March 2012 and from ERA-I reanalysis on (d) 17 March, (e) 18 March, and (f) 19 March 2012.

the front. The dust was then transported westward over the Red Sea along the front and towards the southern Arabian Peninsula. In southern Saudi Arabia, the dust front rapidly advanced to the south and southwest. Figure 4 shows that within a time period of $7 \mathrm{~h}$, the dust front advanced more than $150 \mathrm{~km}$. At 15:00 UTC on 18 March (Fig. 4b), dust was wide spread, with the same maximum dust concentration as those at 08:00 UTC.

Dust and sand lift both ahead of and behind cold fronts; winds tend to be stronger behind the front than ahead of it (Sissakian et al., 2013). Behind an advancing cold front, southern Iraq and northern Saudi Arabia experienced blowing dust or shamal-like conditions (Hamidi et al., 2013).

\subsection{The vertically integrated mass balance and optical depth of the dust}

Dust emissions are calculated in the model interactively from Eq. (1) using simulated surface winds that drive dust emissions. To ensure that the model could adequately generate dust, we compare the simulated $10 \mathrm{~m}$ wind field $\left(U_{10 \mathrm{~m}}\right)$ with the output from the ECMWF Interim global reanalysis, ERA-I. The $U_{10 \mathrm{~m}}$ is extracted from ERA-I and interpolated to WRF projections for comparison. The simulated and reanalysis fields are well correlated (not shown) with a timeaveraged correlation coefficient of 0.79 . Figure 5 a shows the erodibility field $S$ used in Eq. (1) depicting the major dust emission areas. Figure $5 \mathrm{~b}-\mathrm{d}$ shows simulated dust emissions 

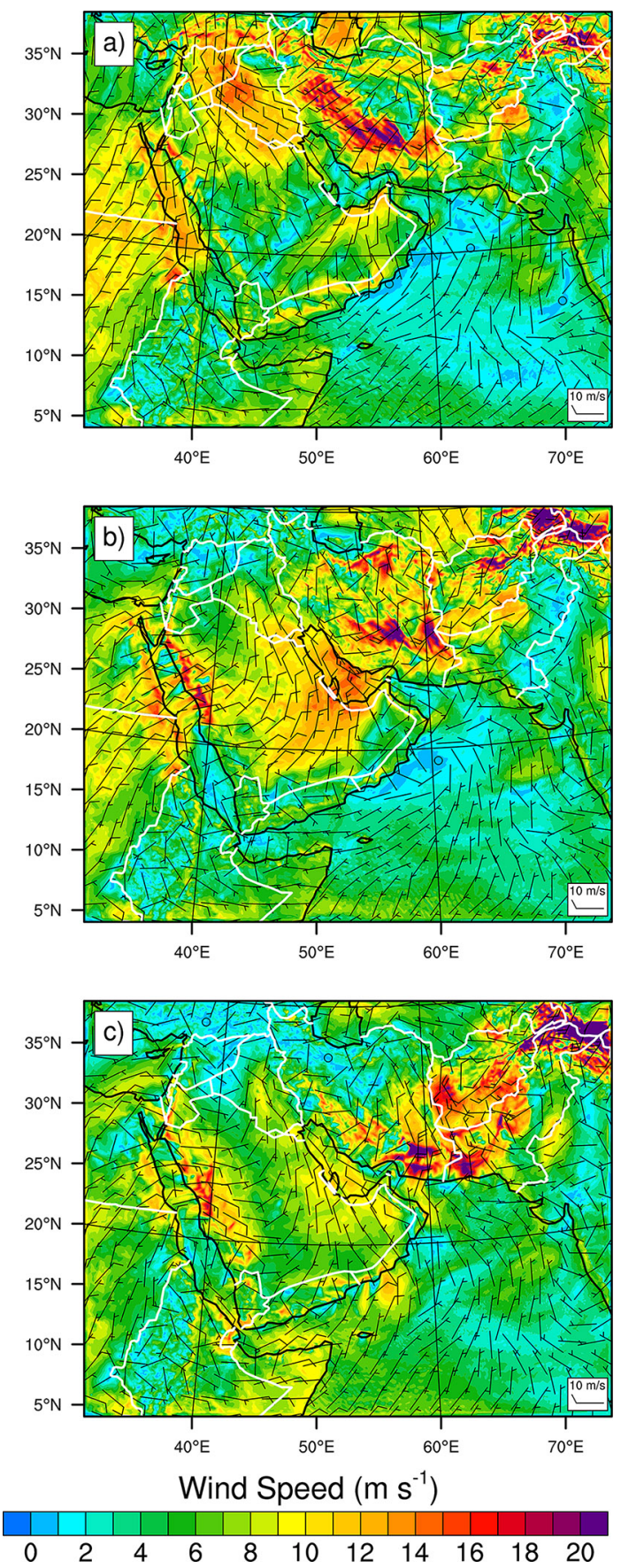

Figure 3. Simulated spatial distribution of $10 \mathrm{~m}$ wind bars and wind speed $\left(\mathrm{m} \mathrm{s}^{-1}\right)$ at 09:00 UTC on (a) 17 March, (b) 18 March, and (c) 19 March 2012.

averaged over $24 \mathrm{~h}$ periods for 17, 18, and 19 March 2012, respectively. On 17 March (Fig. 5b) the most intense simulated emissions were located in the lower Tigris and Euphrates river valleys and in newly dry lakebeds, which are filled with loose fine-grain soils and have high susceptibility. These are known major sources of dust in Iraq. The maximum dust emission rate exceeded $300 \mu \mathrm{g} \mathrm{m}^{-2} \mathrm{~s}^{-1}$. On
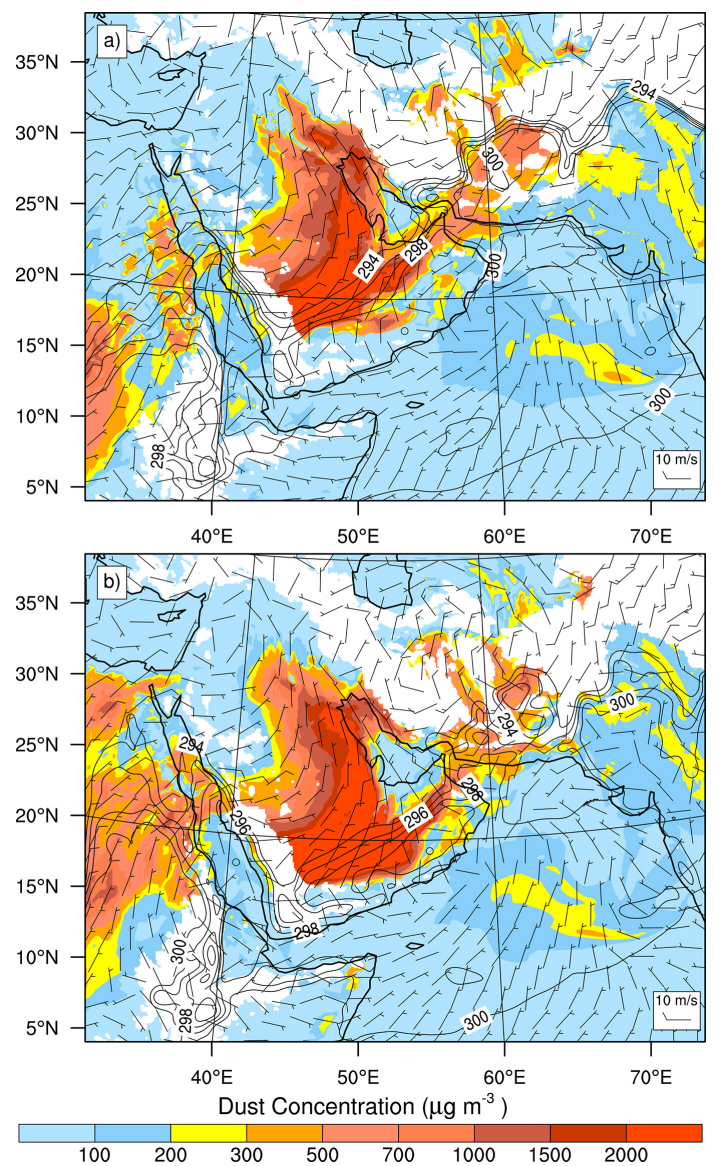

Figure 4. Simulated $10 \mathrm{~m}$ wind bars $\left(\mathrm{m} \mathrm{s}^{-1}\right)$, dust concentration at $900 \mathrm{hPa}\left(\mu \mathrm{g} \mathrm{m}^{-3}\right)$, and $2 \mathrm{~m}$ air temperature $(\mathrm{K})$ at (a) 08:00 UTC and (b) 15:00 UTC on 18 March 2012.

18 March (Fig. 5c) dust was generated in the wide Arabian desert area (The Rub' al Khali, An Nafud, and Ad Dahna) with almost the same maximum intensity as on the previous day. A dust source belt about $50 \mathrm{~km}$ wide along the west coast $\left(22^{\circ} \mathrm{N}\right.$ to $\left.25^{\circ} \mathrm{N}\right)$ of the Arabian Peninsula was also active on 18 March. On 19 March (Fig. 5d) the dust source regions were along the eastern coast of the Persian Gulf, coastal areas of the Arabian Sea near Iran and Pakistan, and on the southern flanks of the mountain chain along the Arabian Sea coast. The active dust source in this region was a small intermountain valley centered at $27.5^{\circ} \mathrm{N}, 59^{\circ} \mathrm{E}$. At the center of this valley, there is a large, $1087 \mathrm{~km}^{2}$, dry salt lake, Hamume Jaz Murian. The majority of dust at the eastern coast of the Persian Gulf was generated from this lake. Dust source regions along the western coast of the Arabian Peninsula were also active. The area of dust generation was relatively compact but maximum dust emissions exceeded $500 \mu \mathrm{g} \mathrm{m}^{-2} \mathrm{~s}^{-1}$ due to strong winds (Fig. 3).

The spatial distribution of daily average simulated dust deposition rates for 17, 18, and 19 March 2012 is shown in Fig. 6. There was no precipitation during the simulation pe- 

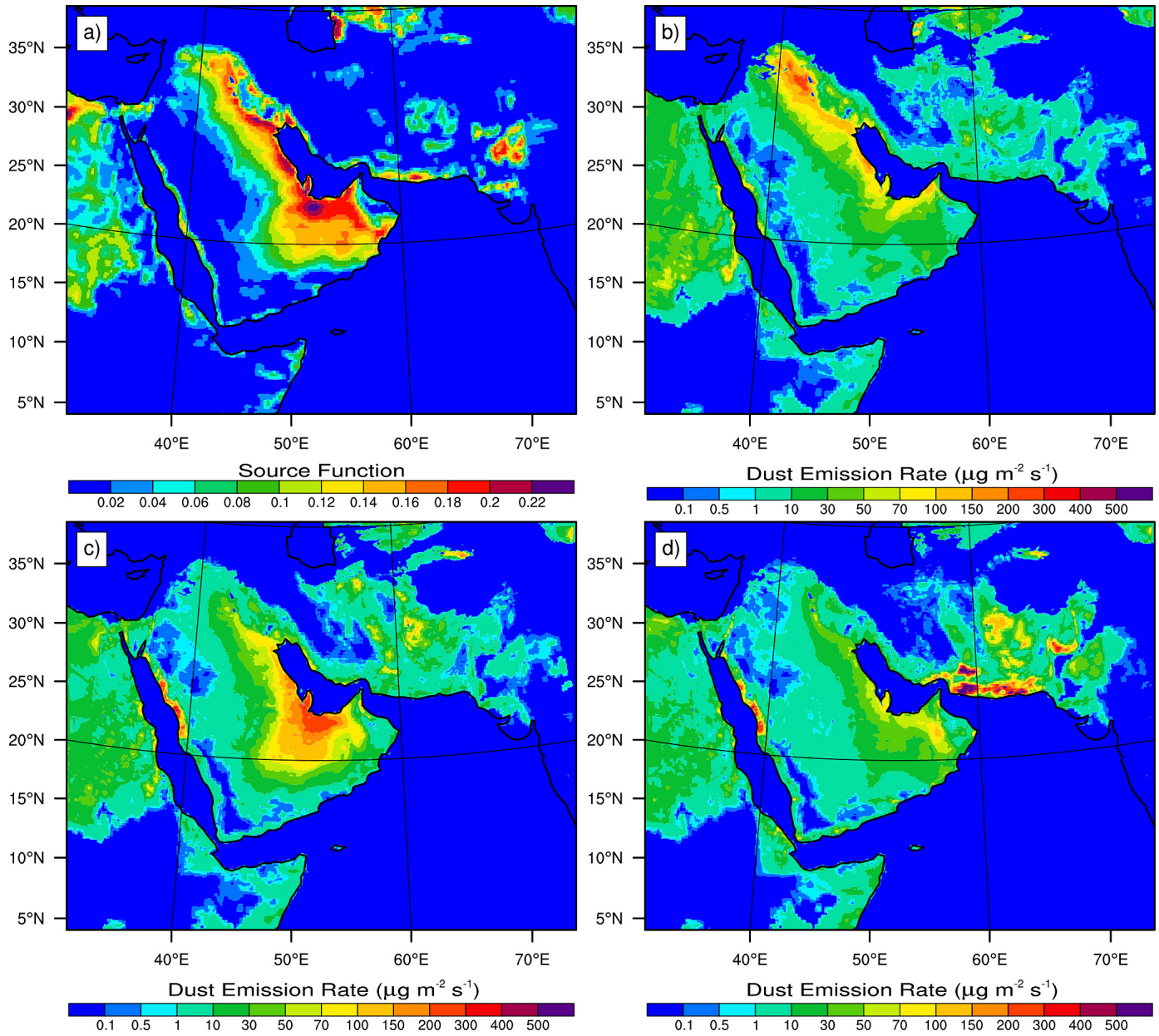

Figure 5. (a) Dimensionless dust erodibility field (S) from the GOCART emission scheme used in simulations; (b) simulated daily mean dust emission rate $\left(\mu \mathrm{g} \mathrm{m}^{-2} \mathrm{~s}^{-1}\right)$ on 17 March 2012; (c) same as (b) but for 18 March 2002; (d) same as (b) but for 19 March 2002.

riod, and therefore the dominant dust removal mechanism was dry deposition. The deposition velocity is higher for large particles, and therefore coarse dust particles tend to deposit closer to a source than the fine ones. Figure 6 shows that the maximum dust deposition exceeds $90 \mu \mathrm{g} \mathrm{m}^{-2} \mathrm{~s}^{-1}$, about one-third of maximum dust emissions rates. On 17 March (Fig. 6a) a lot of dust was deposited in the northeastern Persian Gulf, relatively far from the source regions. On 18 March the strongest dust deposition happened in wide surroundings of the major dust sources; significant amount of dust was deposited in the Persian Gulf and the Red Sea (Fig. 6b). On 19 March (Fig. 6c) dust was deposited in the Red Sea, the Gulf of Oman, and the Arabian Sea off the Iran and Pakistan coasts.

Total dust emission/deposition is computed by integrating emission/deposition over the domain area. Figure 7a shows the time series of daily total emission and deposition (in Mt $\mathrm{day}^{-1}$ ) for the simulation period of 11 to 24 March 2012. The daily emissions $\left(\mathrm{F}_{s}\right)$ and depositions $\left(F_{\mathrm{d}}\right)$ are of the same order of magnitude. The maximum daily emis- sion, $F_{\mathrm{s}}=13.10 \mathrm{Mt} \mathrm{day}^{-1}$, and maximum daily deposition, $F_{\mathrm{d}}=10.06 \mathrm{Mt} \mathrm{day}^{-1}$, occurred on $18 \mathrm{March}$. Dust was dispersed and deposited over much wider areas than those where dust was generated. The maximum total hourly dust emission and deposition rates of $0.85 \mathrm{Mth}^{-1}$ and $0.52 \mathrm{Mt} \mathrm{hr}^{-1}$, respectively, occurred in the daytime at about 07:00 UTC on 18 March (not shown). This is expected because the atmosphere in the daytime is unstable, and the momentum transfer from the free troposphere to the surface, which enhanced the surface winds, is more efficient. Dust emissions are substantially weaker in the night when the boundary layer collapses.

The comparison with other similar studies shows that the dust storm of 18-22 March 2012 is in the range of the most powerful dust events considered in the literature (Zhao et al., 2010; Shao et al., 2003). A portion of the dust deposited in the ocean provides nutrients to marine ecosystems and increases the ocean's net productivity. Dust emitted from southern Iraq, Iran, and the eastern Arabian Peninsula was mainly deposited in the Persian Gulf and the Arabian Sea. Dust emitted from the western coast of the Arabian Peninsula 

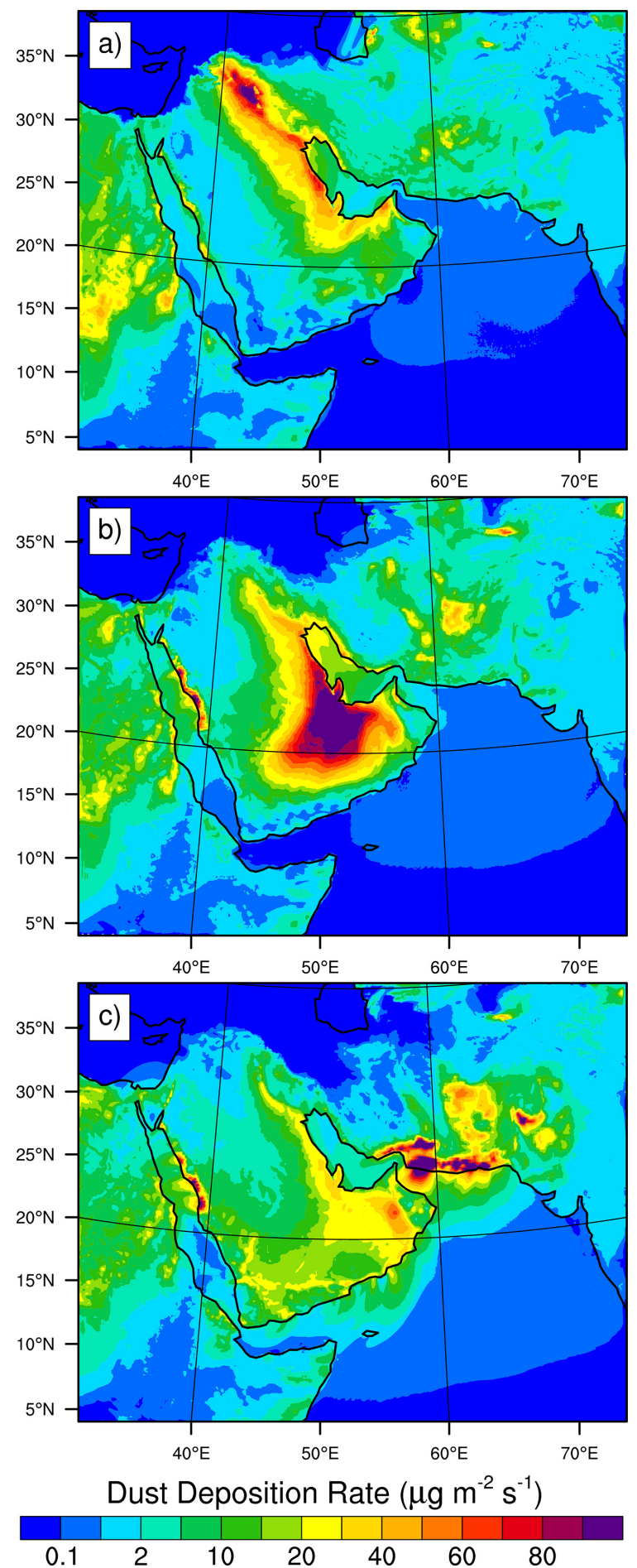

Figure 6. Simulated daily mean dust deposition rate $\left(\mu \mathrm{g} \mathrm{m}^{-2} \mathrm{~s}^{-1}\right)$ on (a) 17 March, (b) 18 March, and (c) 19 March 2012.

was mostly deposited in the Red Sea. Time series of daily total dust deposition over the ocean areas (including the Red Sea, Persian Gulf, and parts of the Arabian Sea that are included in the domain) are plotted in Fig. 7b. Over the ocean areas, the dust load increased in the course of the dust episode
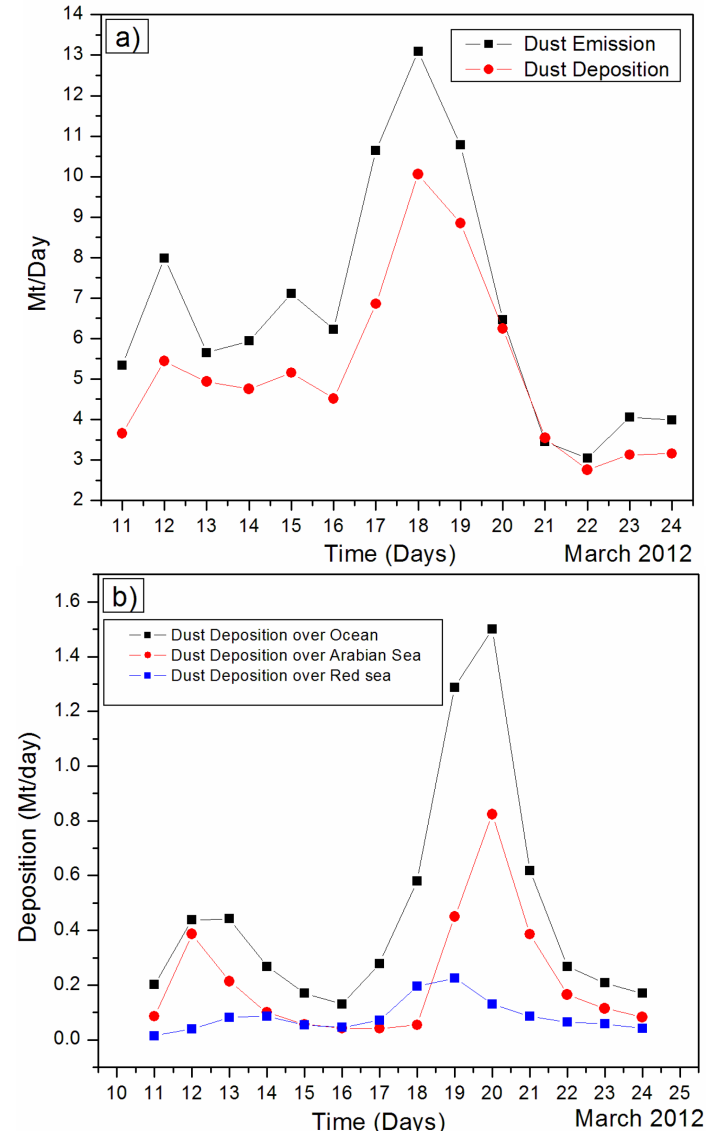

Figure 7. Simulated daily mean domain integrated (a) dust emission (black) and deposition (red) $\left(\mathrm{Mt} \mathrm{day}^{-1}\right.$ ) and (b) dust deposition (Mt day ${ }^{-1}$ ) over all ocean areas within the domain (black), over the Arabian Sea (red), and over the Red Sea (blue) as a function of time.

Table 2. Total emission and deposition over the simulated domain from 11 to 24 March 2012.

\begin{tabular}{lc}
\hline Dust deposition/emission & Dust mass (Mt) \\
\hline Total dust emission & 93.76 \\
Total dust deposition & 73.04 \\
Total ocean deposition & 6.56 \\
Red Sea deposition & 1.20 \\
Arabian Sea deposition & 3.01 \\
Land deposition & 66.48 \\
\hline
\end{tabular}

from 17 to 20 March, reaching its maximum on 20 March. This delay in time is expected, as dust was transported from land to ocean. The maximum dust deposition of $1.5 \mathrm{Mt} \mathrm{day}^{-1}$ over ocean areas also occurred on 20 March. Over the Red Sea, the maximum dust deposition of $0.23 \mathrm{Mt} \mathrm{day}^{-1}$ occurred on 19 March. The dust balance over the entire simulation period is summarized in Table 2. Over the 11-day simulation period, approximately $94 \mathrm{Mt}$ of dust was emitted and $73 \mathrm{Mt}$ of dust was deposited over the entire study domain. The total 

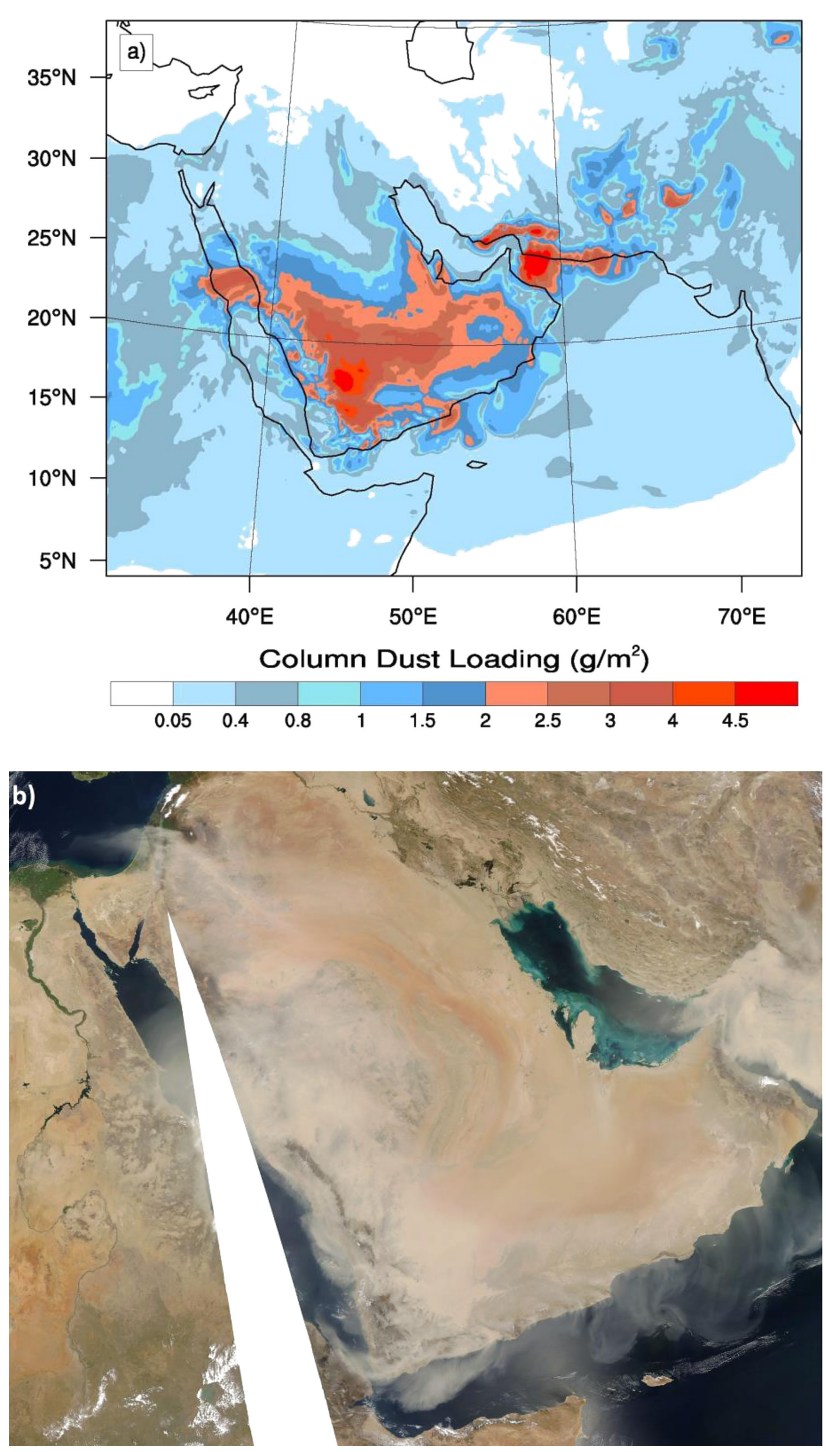

Figure 8. (a) Spatial distribution of simulated dust load $\left(\mathrm{g} \mathrm{m}^{-2}\right)$ at 10:00 UTC on 19 March 2012; (b) combined image taken by Aqua/MODIS at 09:50 UTC and 10:05 UTC on 19 March 2012 showing the dust storm passing over the Arabian Peninsula and Red Sea.

dust deposited on the land was $66.5 \mathrm{Mt}$ and over the ocean $6.5 \mathrm{Mt}$, out of which 1.2 Mt was deposited on the Red Sea.

Although the magnitude of dust deposition over the oceans is not accurately known, there is evidence that dust deposition could have a significant impact on chemical and biological processes in the oceans (Martin, 1990; Watson et al., 2000; Fan et al. 2006; Sunda and Huntsman, 1997). In the present study, we have calculated the amount of dust deposited over the ocean and particularly in the Red Sea. Aeolian deposition is especially important for the Red Sea because this sea has very little fresh water discharge from the coastal areas that is mostly associated with flash flood events.
To calculate the total frequency and spatial distribution of severe dust events over the Arabian Peninsula and the Red Sea region, we choose to analyze the MODIS satellite images for the 2002-2013 period, which were provided under the scope of natural hazard reports in this area by NASA's rapid response system (http://earthobservatory.nasa. gov/NaturalHazards). For this 12-year period, the number of cases when a dust plume covered more than $20 \%$ of the Middle East area reached 237 or approximately 20 annually. The number of dust storms, which affected the Red Sea, was 71 or 5-6 annually. We counted dust events based on their extent and optical depth. The obtained number of regional storms is consistent with the results of previous studies (e.g., Rezazadeh et al., 2013 and Prospero et al., 2002). Assuming this storm frequency and dust deposition of $1.2 \mathrm{Mt}$ per storm, as calculated in this study, we estimate the total annual mineral dust deposition on the Red Sea to be at least $6 \mathrm{Mt}$. An extended analysis of the intensity and variability of the dust storm activity over the Arabian Peninsula, as well as contribution of dust deposition during fair weather conditions, are required to make this estimate more certain.

Figure 8a shows the simulated spatial pattern of the dust load at 10:00 UTC on 19 March. Dust plumes were seen spreading over the Gulf of Oman, the Red Sea, and the southern coast of the Arabian Peninsula. The highest vertically integrated dust load exceeded $4.5 \mathrm{~g} \mathrm{~m}^{-2}$ over the Gulf of Oman and southern Saudi Arabia bordering Yemen. The image taken by Aqua/MODIS at 09:50-10:05 UTC (Fig. 8b) shows a significant dust load over the entire southern Arabian Peninsula and its coastline along the Arabian Sea as well as over the Persian Gulf. The simulated spatial distributions of the dust loads in Fig. 8a are quite consistent with the MODIS dust plume image in Fig. $8 \mathrm{~b}$ at most locations, suggesting that the model correctly predicted the dust event. Both model simulations and satellite imagery clearly show dust aerosols covering not only the land but also very large areas of the oceans.

Figure 9a-c shows a spatial distribution of AOD from WRF-Chem, MODIS, and SEVERI retrievals. Since the number of passes of the MODIS instrument on-board the Aqua satellite over the domain of interest during the time of interest is limited, two $0.55 \mu \mathrm{m}$ retrievals at 09:50 and 10:05 UTC on 19 March were used for comparisons with the simulated AOD $(0.60 \mu \mathrm{m})$ at 10:00 UTC. A combination of both standard ocean and deep blue products was used to get the maximum spatial coverage over the simulated domain. The model captures the spatial distributions of AOD well. Both modeled and observed optical fields indicate a high dust plume over the Persian Gulf, Gulf of Oman, Red Sea, and southern Arabian Peninsula.

Figure 9d-f compares hourly simulated and observed AODs at three AERONET sites (KAUST campus, Kuwait University, and Mezaira) during the simulation period. The AERONET $15 \mathrm{~min}$ observations were averaged hourly to compare with modeled values. The time series match well 

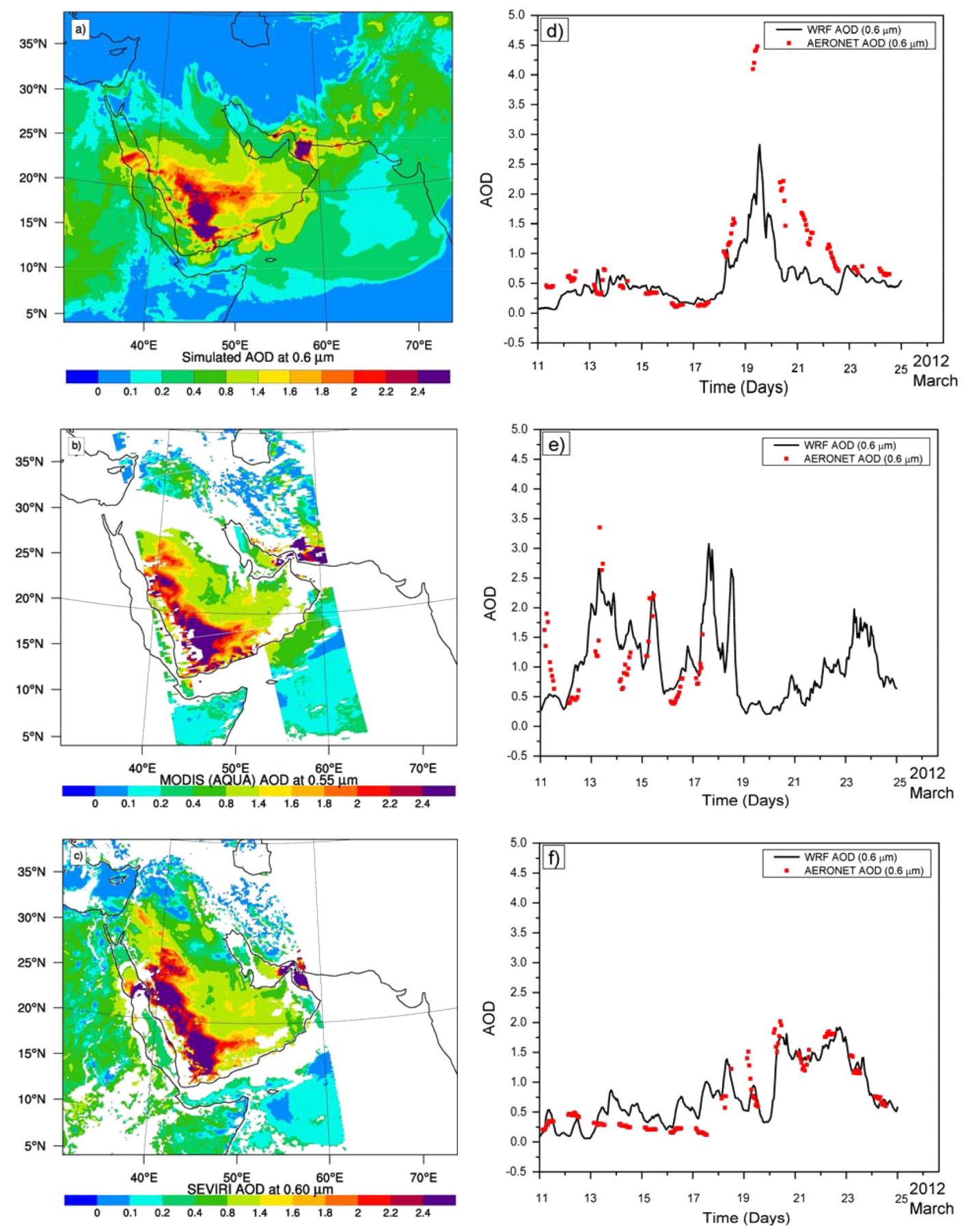

Figure 9. Spatial distribution of AOD on 19 March 2012 from (a) WRF-Chem simulations at 10:00 UTC, (b) MODIS (combined standard ocean and deep blue products) at 09:50-10:05 UTC, (c) SIVIRI at 10:00 UTC, and 0.60 $\mu$ m AOD from the WRF-Chem simulations (black solid line) at AERONET sites and AERONET observations (red dots) at (d) KAUST Campus, (e) Kuwait University, and (f) Mezaira.

with each other most of the time. Even though the magnitude of the simulated AOD at the KAUST campus was lower compared to that of AERONET on 19 March, the simulations were able to reproduce the peak and the temporal dependence quite well.

\subsection{Vertical mixing of dust within the boundary layer and free troposphere}

The vertical distribution of dust aerosols is important for estimating their radiative effect and their impact on circulation and climate (Forster et al., 2007; Claquin et al., 1998; Huang 

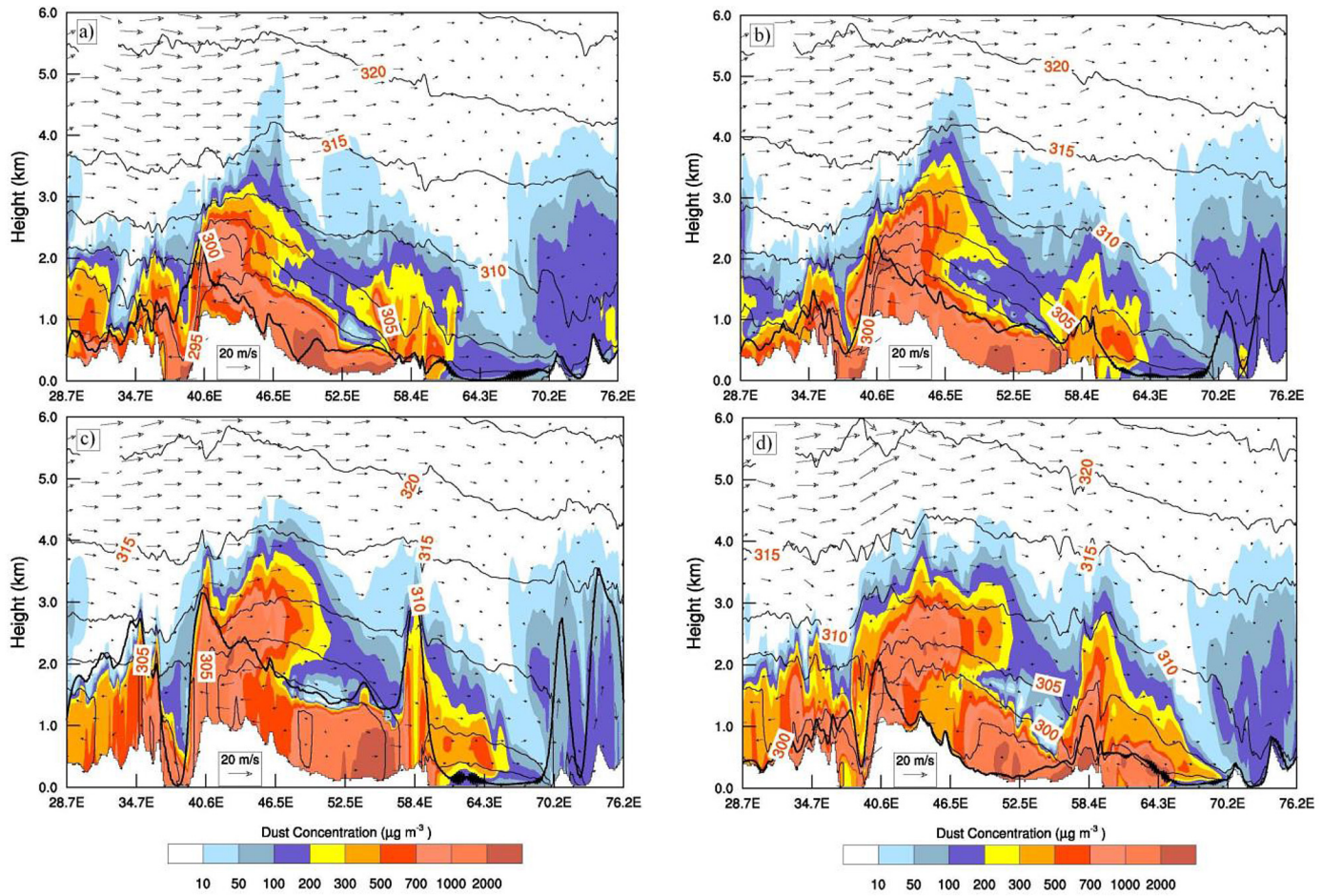

Figure 10. The height longitude cross section along $21.7^{\circ} \mathrm{N}$ showing dust concentration ( $\mu \mathrm{g} \mathrm{m}{ }^{-3}$, shading) and PBL height (km) shown by the black solid line from WRF-Chem on 19 March 2012 at (a) 00:00 UTC, (b) 06:00 UTC, (c) 12:00 UTC, and (d) 18:00 UTC.

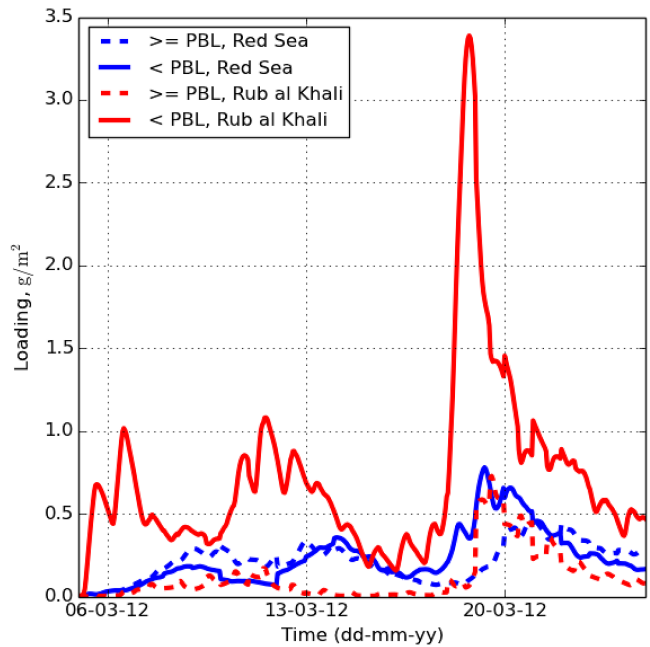

Figure 11. Domain-averaged dust loading $\left(\mathrm{g} \mathrm{m}^{-2}\right)$ above (solid line) and below (dash line) daily maximum PBL heights for land (red) and ocean (blue) areas as a function of time for the entire period of simulations.

et al., 2009; Zhu et al., 2007). The evolution and diurnal cycle of the atmospheric boundary layer directly affects the life cycle and vertical redistribution of dust particles (Cuesta et al., 2009).

\subsubsection{Vertical structure of a dust layer}

Most dust aerosols reside in the atmospheric boundary layer. The portion of aerosols that moves above the boundary layer to the free troposphere is subject to long-range transport and therefore is of particular interest. N'Tchayi Mbourou et al. (1997), Engelstaedter et al. (2006), and Chaboureau et al. (2007) reported that the diurnal cycle of dust in the Sahel and Sahara is the result of daytime boundary-layer dry convection affecting the uplift and transport of dust in the almost $6 \mathrm{~km}$ deep boundary layer (Gamo, 1996; Carolina and Martin, 2012). The planetary boundary layer (PBL) can be influenced by different mechanisms associated with the coastal breezes, terrain, and surface properties (Warner and Sheu, 2000). The Asir mountain range in western Arabia runs along the Red Sea coast and is highest in the south where its altitude reaches $3 \mathrm{~km}$. During the day, the surfaces of the mountains heat the air higher up in the atmosphere quicker than the ocean surface can. This leads to enhancing subsidence over the Red Sea and suppresses the growth of daytime PBL (e.g., Kuwagata and Kimura, 1995; Whiteman, 1982; Kimura and Kuwagata, 1995; Bader and McKee, 1983). Upward motion over heated elevated terrain during the day causes the vertical temperature profile to become less stable and thus possibly tends to increase the PBL height over the Asir mountains.

Figure 10 shows the diurnal cycle of simulated vertical profiles of dust concentration, potential temperature, wind 

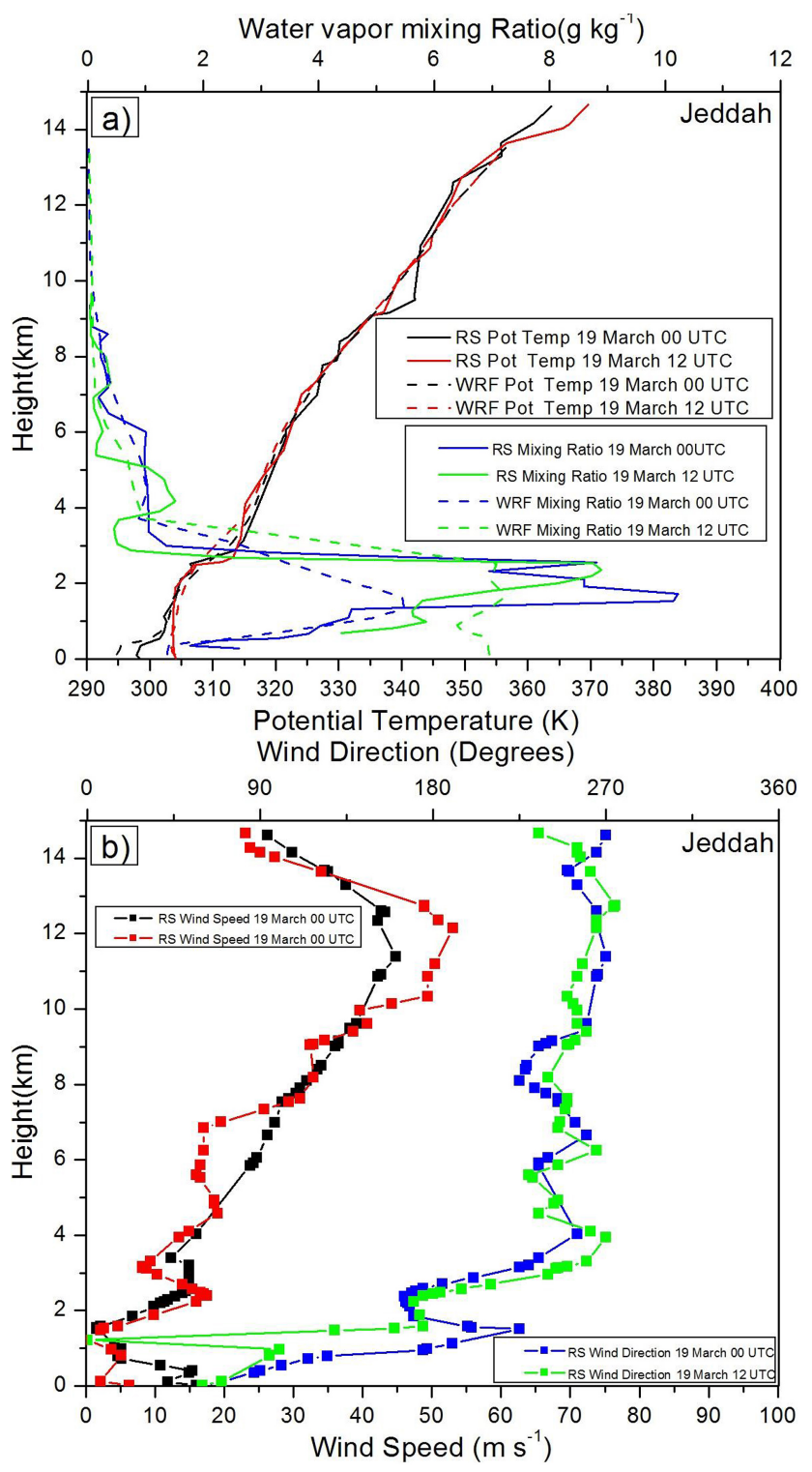

Figure 12. (a) Simulated (dashed lines) and RS profiles of potential temperature and water vapor mixing ratio $\left(\mathrm{g} \mathrm{kg}^{-1}\right)$ at the Jeddah's King Abdulaziz International Airport at 00:00 and 12:00 UTC on 19 March 2012; (b) vertical profiles of wind direction (degrees) (blue and green) and wind speed ( $\mathrm{m} \mathrm{s}^{-1}$ ) (red and black) from radiosonde soundings at the Jeddah's King Abdulaziz International Airport at 00:00 and 12:00 UTC on 19 March 2012.

vector, and PBL height in the altitude/longitude cross section at $21.7^{\circ} \mathrm{N}$ on $19 \mathrm{March} 2012$. The aerosol concentration reaches $2000 \mu \mathrm{g} \mathrm{m}^{-3}$. The thick dust plume stretches from $28.7^{\circ} \mathrm{E}$ to $70.2^{\circ} \mathrm{E}$. At 06:00 UTC heating has just started, and the PBL height nearly follows the topography. Over mountain and desert areas, the PBL is shallow. The inland convection increases, and enhanced subsidence over the Red Sea suppresses the growth of the PBL. The sea breeze starts developing at about 07:00 UTC. At 12:00 UTC this process continues but much more slowly as the sea breeze front moves inland and the PBL height grows farther to the east. A well-mixed, deep boundary layer in our simulations develops during the day up to the height of $3.5 \mathrm{~km}$ in the afternoon as seen in Fig. 10c. At night, the PBL collapses, resulting in an elevated dust-laden residual boundary layer above the surface inversion (Fig. 10d).

The temporal PBL variability is characterized by the more rapid PBL growth over the high elevations in the western Arabian Peninsula early in the heating cycle. The high PBL then spreads towards the eastern Peninsula. During the night, the nocturnal jets contribute to the dust mobilization close to the surface, while aerosol particles increasingly sediment from the residual layer after the collapse of the PBL. The peak of dust vertical mixing is observed at about 12:00 UTC (Fig. 10c) over the Asir mountains in southwestern Saudi Arabia, where a significant amount of dust penetrates in the free troposphere downwind of the Asir mountain ridge.

To quantify the amount of dust mixed above the boundary layer, we calculate the domain average loading below and above the diurnal maximum PBL height (Fig. 11) that approximates the top of a residual layer. Aerosols remaining in the residual layer will be again entrained in the PBL during the next diurnal cycle; therefore we assume that only aerosols above the residual layer are disconnected from the surface. Because the PBL dynamics are different over land and over the sea, we did these calculations separately for the land and ocean areas within the model domain. Figure 11 shows that during the simulation period, approximately $15 \%$ of dust over land is in the free troposphere. Over the sea, it is often more than $50 \%$. The storm increased the dust loading over land by approximately $30 \%$ and almost tripled it over the sea.

To assess the simulated vertical structure of the atmosphere we used RS soundings from the Jeddah's King Abdulaziz Airport $\left(21.7^{\circ} \mathrm{N}, 39.18^{\circ} \mathrm{E}\right)$. The model and RS profiles of the water vapor mixing ratio and potential temperature (Fig. 12a) show that the PBL height on 19 March 2012 at 00:00 and 12:00 UTC is captured well by the model. The simulated PBL height was approximately $3 \mathrm{~km}$ in the afternoon as seen in Fig. 10c, which is in good agreement with the position of the inversion layer from Jeddah's soundings (Fig. 12a). The potential temperature at 12:00 UTC (Fig. 12a) is almost constant between the ground and $3 \mathrm{~km}$ altitude as a result of strong mixing in the PBL. The RS vapor mixing ratio profile also shows the mixing height to be at $3 \mathrm{~km}$. The vertical profile of the magnitude and direction of the horizontal wind over Jeddah from RS profiles on 19 March (00:00 and 12:00 UTC) is shown in Fig. 12b. The wind direction shows a strong diurnal change in the boundary layer at $1 \mathrm{~km}$ altitude. The wind over Jeddah was found to be east/southeast in the lowest $1 \mathrm{~km}$ and mostly west/northwest above $3 \mathrm{~km}$. The wind speed exceeds $15 \mathrm{~m} \mathrm{~s}^{-1}$ near the surface and is more than $50 \mathrm{~m} \mathrm{~s}^{-1}$ at $12 \mathrm{~km}$. The surface wind at 00:00 UTC is enhanced by the land breeze. This is a very 

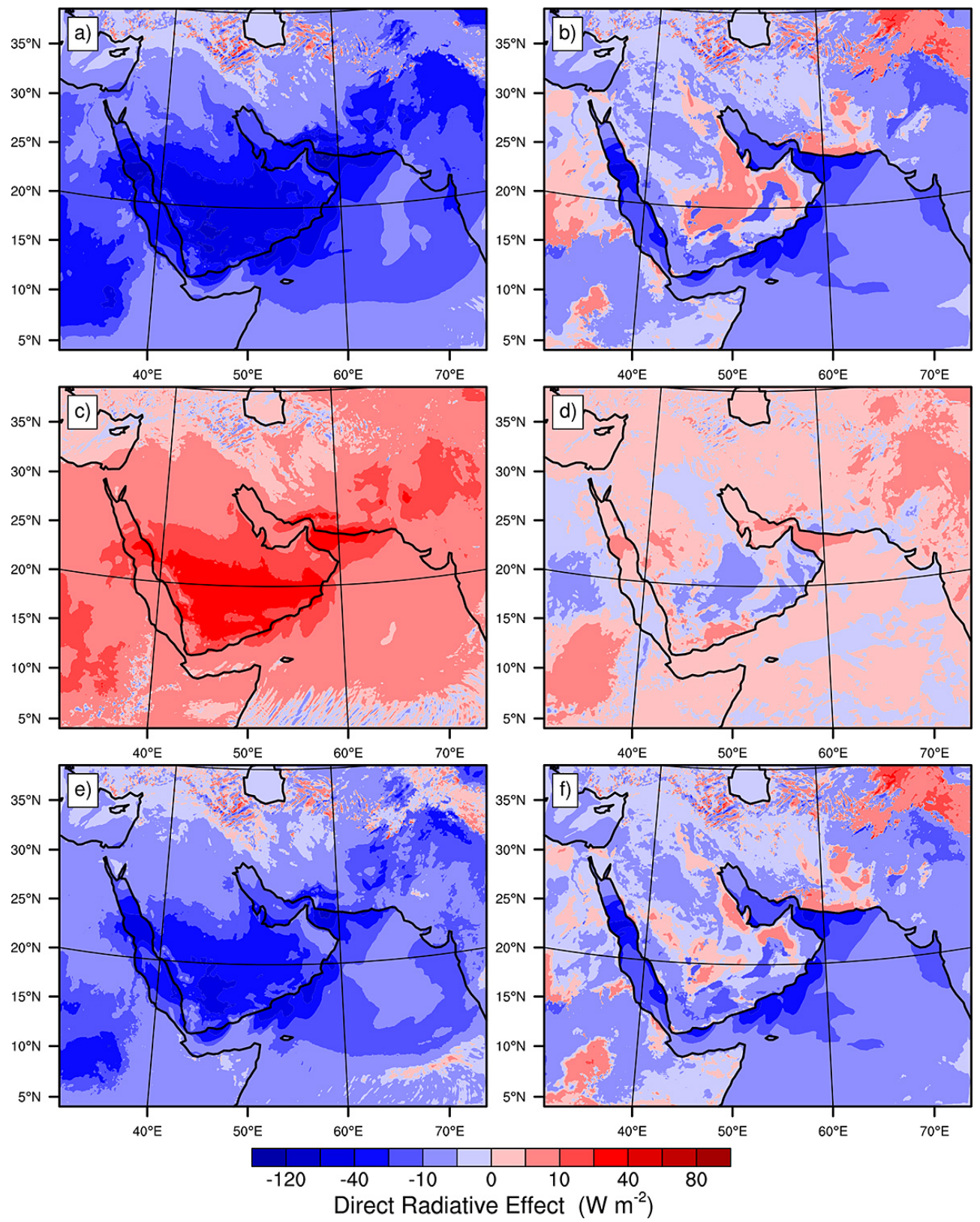

Figure 13. Simulated daily mean clear sky direct radiative effect (DRE) of dust aerosols $\left(\mathrm{W} \mathrm{m}^{-2}\right)$ on 19 March 2012: (a) SW DRE at BOA, (b) SW DRE at TOA, (c) LW DRE at BOA, (d) LW DRE at TOA, (e) net DRE at BOA and (f) net DRE at TOA. Positive values correspond to the heating of the atmospheric column and underlying surface.

important factor for the transport and deposition of dust over the Red Sea during the nighttime (Fig. 10a, d).

\subsection{The direct radiative effect of dust}

Aerosols directly influence the Earth's radiative budget by absorbing, scattering, and emitting LW radiation (Cautenet et al., 1991; Markowicz et al., 2003; Ackerman and Chung, 1992; Haywood et al., 2005) and scattering and absorbing SW radiation (direct effect) (Tegen et al., 1996; Haywood and Boucher, 2000; Harrison et al., 2001; Haywood et al., 2001; Sokolik et al., 2001), and indirectly by altering cloud droplet size distribution (indirect effect) (Twomey, 1977; Albrecht, 1989). Because there is little cloudiness over deserts, the direct radiative effect (DRE) of dust is of primary interest in this study. The surface SW cooling by dust results in large reductions in latent and sensible heat fluxes from the surface to the atmosphere (Miller et al., 2004b; Shell and Somerville, 2007). This reduces the turbulent energy within the PBL and the downward transport of momentum to the 


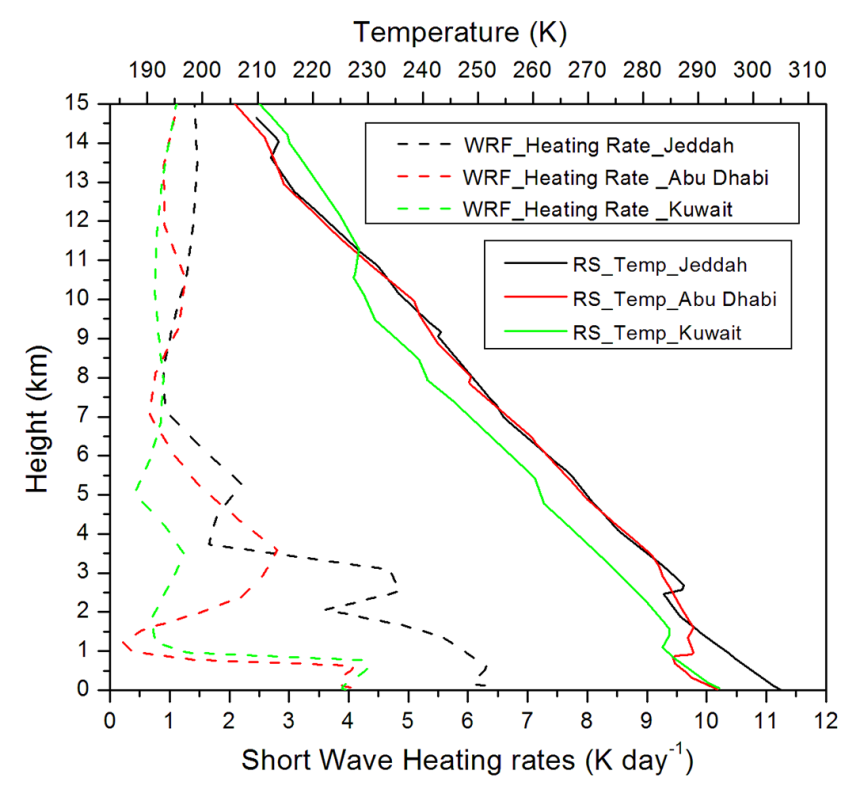

Figure 14. Simulated (dashed lines) solar heating rates profiles in the atmosphere over Jeddah (black), Abu Dhabi (red), and Kuwait (green) sites and radiosounding temperature profiles at the same locations (solid lines) at 12:00 UTC on 19 March 2012.

surface, which suppresses the surface wind speed and dust generation (Miller et al., 2004a). In the troposphere, the absorption of both incoming and reflected solar radiation, as well as emission of thermal radiation by dust particles, affects the air temperature and circulation (Alpert et al., 1998; Miller and Tegen, 1998; Sathesh et al., 2007). Depending on their physical and optical properties as well as their chemical composition, aerosols exert a cooling or warming influence on the atmosphere and underlying surface (e.g., Chylek and Wong, 1995; Sokolik and Toon, 1996; Miller and Tegen, 1998; Ahn et al., 2007; Shell and Somerville, 2007; Balkanski et al., 2007). Large uncertainties in the assessment of the radiative impact of mineral dust on regional and global scales have been pointed out in a number of early and recent studies (Sokolik and Toon 1996; Tegen et al., 1996; Carlson and Benjamin, 1980; Sokolik and Golitsyn, 1993; Ackerman, 1997; Liao and Seinfeld, 1998a; Claquin et al., 1998; Stier at al., 2007).

To assess the DRE of dust aerosols we calculate the change of total clear-sky radiative flux $\Delta F$, at the top of the atmosphere (TOA) and at the bottom of the atmosphere (BOA) and in simulations when aerosols are present $\left(F^{A}\right)$ and absent $\left(F^{C}\right)$. Then the DRE can be defined at BOA and TOA as

$$
\begin{aligned}
& \Delta F_{\mathrm{BOA}}=F_{\mathrm{BOA}}^{\downarrow A}-F_{\mathrm{BOA}}^{\uparrow A}-F_{\mathrm{BOA}}^{\downarrow C}+F_{\mathrm{BOA}}^{\uparrow C}, \\
& \Delta F_{\mathrm{TOA}}=F_{\mathrm{TOA}}^{\uparrow C}-F_{\mathrm{TOA}}^{\uparrow A},
\end{aligned}
$$

where the arrows indicate the direction of the fluxes: $\downarrow$ denotes a downward flux and $\uparrow$ an upward flux. This convention
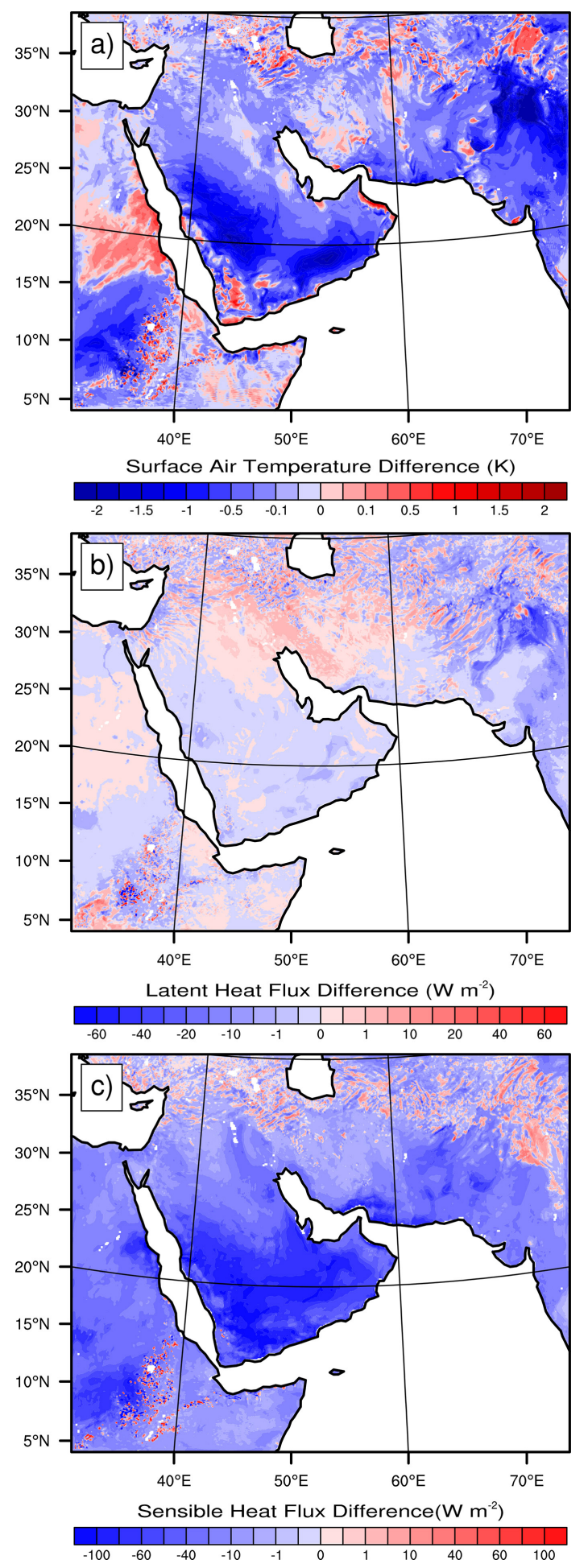

Figure 15. Simulated instantaneous differences in (a) air temperature $(\mathrm{K})$, (b) latent heat flux $\left(\mathrm{W} \mathrm{m}^{-2}\right)$, and (c) sensible heat flux $\left(\mathrm{W} \mathrm{m}^{-2}\right)$ in the runs with and without dust aerosols at 12:00 UTC on 19 March 2012. 
is used for both LW and SW radiation. Definitions (Eqs. 4 and 5) imply that negative values of $\Delta F$ at the BOA and TOA are associated with an aerosol cooling effect, while positive $\Delta F$ is associated with warming. The DRE, as defined here, is different from a conventional instantaneous direct radiative forcing (DRF) because it includes model responses (see, e.g., Stenchikov et al., 1998). However, the clear-sky SW DRE discussed below should be a fairly good approximation of the clear-sky SW DRF.

\subsubsection{The shortwave radiative effect}

The spatial distributions of daily average clear sky SW, LW, and net $(\mathrm{SW}+\mathrm{LW})$ dust DRE at BOA and TOA on 19 March are shown in Fig. 13. The SW DRE is mostly negative at the surface, reaching $-134 \mathrm{~W} \mathrm{~m}^{-2}$ (Fig. 13a). The domainaveraged SW DRE at BOA equals $-16 \mathrm{Wm}^{-2}$ and tends to cool the surface. The daily averaged SW DRE at TOA over desert areas is about $10 \mathrm{~W} \mathrm{~m}^{-2}$ and tends to warm the surface-atmosphere system over the desert (Fig. 13b). However, the domain-average SW DRE at TOA equals $-4.25 \mathrm{~W} \mathrm{~m}^{-2}$. The warming effect of dust aerosols over desert surfaces is largely explained by two factors: absorption of solar radiation by dust and high reflectance of the underlying surface. Dust absorbs and scatters the SW radiation. Both these effects reduce the downward flux at BOA but tend to compensate for each other at TOA. Therefore, the BOA cooling effect is robust, but the TOA warming is very sensitive to the dust's single scattering albedo and surface reflectivity. Over the ocean, the SW DRE at TOA is negative due to the smaller ocean albedo. Over the ocean, the dust layer increases the outgoing SW radiation since it is a much better reflector than the underlying dark water. The negative values of SW DRE at TOA over the ocean are consistent with the results from Perez et al. (2006) for Mediterranean dust. Daily averaged SW BOA aerosol effect up to $-21.1 \mathrm{Wm}^{-2}$ was reported by McFarlane et al. (2009) during the atmospheric radiation measurement mobile facility deployment in Niamey and Niger. During the winter monsoon season, Satheesh et al. (2006) reported daily averaged surface SW radiative effect from -23.6 to $12 \mathrm{~W} \mathrm{~m}^{-2}$ over the Arabian Sea for 8 years from 1995 to 2002 with a maximum instantaneous value of $-51 \mathrm{~W} \mathrm{~m}^{-2}$. During the summer monsoon season, the daily averaged surface $\mathrm{SW}$ radiative effect was in the range of -24.2 to $-13.1 \mathrm{~W} \mathrm{~m}^{-2}$ with a "maximum" instantaneous value of $-45 \mathrm{~W} \mathrm{~m}^{-2}$. At TOA, the $\mathrm{SW}$ radiative effect of dust was in the range of -16.5 to $-9.1 \mathrm{Wm}^{-2}$ during the summer monsoon and -7.3 to $-6.0 \mathrm{~W} \mathrm{~m}^{-2}$ during the winter monsoon. Haywood et al. (2003) revealed an instantaneous direct SW radiative effect at BOA from a large Saharan dust plume, advected off the coast of western Africa, to be approximately $-130 \mathrm{~W} \mathrm{~m}^{-2}$. The maximum instantaneous SW DRE at the surface in this study was $-449 \mathrm{~W} \mathrm{~m}^{-2}$ on 19 March 2012.
Table 3. Summary of domain average values of daily mean clear sky direct radiative effect (DRE) for shortwave (SW), long-wave (LW) and net $(\mathrm{SW}+\mathrm{LW})$ radiation at top of the atmosphere (TOA), and bottom of atmosphere (BOA) on 19 March 2012.

\begin{tabular}{cccc}
\hline Level & $\begin{array}{c}\text { SW DRE } \\
\left(\mathrm{W} \mathrm{m}^{-2}\right)\end{array}$ & $\begin{array}{c}\text { LW DRE } \\
\left(\mathrm{W} \mathrm{m}^{-2}\right)\end{array}$ & $\begin{array}{c}\text { Net DRE } \\
\left(\mathrm{W} \mathrm{m}^{-2}\right)\end{array}$ \\
\hline TOA & -4.25 & 0.25 & -4.00 \\
BOA & -16.00 & 6.00 & -10.00 \\
\hline
\end{tabular}

\subsubsection{The long-wave radiative effect}

Figure $13 \mathrm{c}$ and $\mathrm{d}$ shows that the daily averaged LW DRE is mostly positive at TOA and BOA and is larger at the surface. Dust absorbs terrestrial radiation coming from the surface and atmosphere and generally re-emits it at lower temperatures than the underlying surface. The presence of dust reduces the outgoing $\mathrm{LW}$ radiation and increases the downward TOA LW flux. The maximum daily average LW DRE at the surface is $43 \mathrm{~W} \mathrm{~m}^{-2}$ with a domain average value of $6 \mathrm{~W} \mathrm{~m}^{-2}$. At TOA, the maximum daily average value of LW DRE is $8.4 \mathrm{~W} \mathrm{~m}^{-2}$ with a domain average value of $0.25 \mathrm{~W} \mathrm{~m}^{-2}$. The $\mathrm{LW}$ warming can offset the $\mathrm{SW}$ cooling effect of dust at TOA. Zhang and Christopher (2003) estimated the dust aerosol LW TOA DRE over the Sahara from instruments on-board a satellite and showed that there is a strong warming effect of $7 \mathrm{~W} \mathrm{~m}^{-2}$ over the cloud-free Sahara regions for September 2000 and, when averaged over six regions from the study area, the LW TOA DRE ranges from -1 to $15 \mathrm{~W} \mathrm{~m}^{-2}$. Liao and Seinfeld (1998a) reported LW BOA DRF ranging from 0.9 to $1.4 \mathrm{~W} \mathrm{~m}^{-2}$ for the $0.1 \mathrm{~g} \mathrm{~m}^{-2}$ dust loading using a one-dimensional column radiation model. From low dust loading under dry tropics atmospheric conditions, Sokolik et al. (1998) calculated the LW DRF at BOA in the range of 7 to $14 \mathrm{~W} \mathrm{~m}^{-2}$ and the LW DRF at TOA in the range of 2 to $7 \mathrm{~W} \mathrm{~m}^{-2}$. We found that under dust storm conditions, the LW DRE at the surface varies between 50 and $80 \mathrm{~W} \mathrm{~m}^{-2}$ and the LW DRE at TOA varies between 15 and $25 \mathrm{~W} \mathrm{~m}^{-2}$. It is smaller but comparable with the SW DRE.

\subsubsection{Net DRE}

Figure $13 \mathrm{e}$ and $\mathrm{f}$ shows the net $(\mathrm{SW}+\mathrm{LW}) \mathrm{DRE}$ at BOA and TOA, respectively. At the surface, the net DRE is negative in most of the region with an extreme value of $-94 \mathrm{Wm}^{-2}$. The strong negative net DRE at BOA is seen over the region where the model and satellites show the highest dust atmospheric loading (Fig. 8). In Fig. 13 the domain average value of net DRE is $-10 \mathrm{~W} \mathrm{~m}^{-2}$ and $-4 \mathrm{~W} \mathrm{~m}^{-2}$ at BOA and TOA, respectively. The SW DRE exceeds the LW DRE at both BOA and TOA. Figure 13e and $f$ shows that net DRE causes cooling at the surface, while at the TOA it causes warming over the land but cooling over the oceans. This pattern in the net DRE agrees with that found by Yue et al. (2010), 
Ackerman and Chung (1992), Woodward (2001), and Liao et al. (2004). The sign of the net DRE at TOA could be either positive (warming) or negative (cooling) depending on several key variables, such as the surface albedo, particle size, vertical distribution of dust, optical depth, and the imaginary part of the dust refractive index (Tegen and Lacis, 1996; Liao and Seinfeld, 1998a, b). In this study, the imaginary part of the dust refractive index is set to 0.003 for the entire SW spectrum. Table 3 summarizes the domain average SW, LW, and Net DRE at TOA and BOA for 19 March 2012.

\subsubsection{Atmospheric heating rates}

The rate of change of temperature in an atmospheric layer $\left(\mathrm{K} \mathrm{day}^{-1}\right)$ due to radiative heating/cooling is called the radiative heating/cooling rate. The simulated instantaneous dustinduced perturbations (similar to definitions Eqs. 4 and 5) of SW heating rates over Jeddah, Abu Dhabi, and Kuwait at 12:00 UTC on 19 March are shown in Fig. 14. The available temperature profiles at 12:00 UTC from RS are also shown. The heating rates vary with the altitude following the vertical distribution of the aerosols. The maximum heating rates over Kuwait $\left(\sim 4.4 \mathrm{~K} \mathrm{day}^{-1}\right)$ and Abu Dhabi $\left(\sim 4 \mathrm{~K} \mathrm{day}^{-1}\right)$ are at approximately $1 \mathrm{~km}$ altitude. The heating rates reach their maximum value at $3 \mathrm{~km}$ over Jeddah $\left(\sim 4.9 \mathrm{~K} \mathrm{day}^{-1}\right)$. Over Mezaira (not shown), the dust-generated heating rates in the lower troposphere reach $9 \mathrm{~K} \mathrm{day}^{-1}$. The maximum heating over Kuwait and Abu Dhabi is at lower levels compared to that over Jeddah. This is because Kuwait and Abu Dhabi are closer to the dust source regions and hence there is more dust in the lower levels of the atmosphere.

The RS temperature profiles help to clarify the effect of aerosols on the vertical structure of the atmosphere under storm conditions. All RS temperature profiles show strong inversions above the layers with maximum heating rates. These inversions are formed by absorption of SW radiation at the top of a dense aerosol layer and further mixing above this layer. The temperature inversion is quite strong: e.g., over Jeddah at $2.5 \mathrm{~km}$ altitude, it reaches $4.4 \mathrm{~K}$ and significantly affects the atmospheric and dust dynamics by preserving a dense aerosol layer near the surface. Reported heating rates from the Arabian dust storm are consistent with the figures in the literature for other locations. Lemaitre et al. (2010) reported average dust heating rates to be between 1.5 and $4 \mathrm{~K} \mathrm{day}^{-1}$ depending on the altitude and location of a dust event observed over Benin and Niger, which is comparable with the maximum heating rate over Kuwait $\left(\sim 4.5 \mathrm{~K} \mathrm{day}^{-1}\right)$ in our study. The instantaneous heating rates they observed were as high as $8 \mathrm{Kday}^{-1}$ in some limited areas, which is comparable with the strong heating of $9 \mathrm{~K} \mathrm{day}^{-1}$ observed at Mezaira near Abu Dhabi.

The radiative heating/cooling by dust must be taken into account to predict the overall impact of aerosols on atmospheric circulation. Karyampudi and Carlson (1988) showed that radiative heating by Saharan dust helps to maintain a warm and deep Saharan air layer over the ocean, enhancing the strength of the mid-level easterly jets and reducing the convection within the equatorial zone. Chen et al. (1994) showed that the radiative heating rates of dust could affect the evolution of a dust storm, leading to stronger surface frontogenesis. They suggested that the heating rates could significantly affect mesoscale weather systems in arid and desert regions.

\subsection{Meteorological responses to the dust DRE}

Figure 15 presents our simulated spatial distributions of instantaneous changes in surface air temperature and latent and sensible heat fluxes caused by the dust over land at 12:00 UTC on 19 March 2012. The surface air temperature over the majority of the study domain cools in response to the net dust radiative effect. The temperature changes by up to $-6.7 \mathrm{~K}$. A number of previous studies demonstrated similar magnitudes of the short-term impacts of dust on surface temperature (Han et al., 2013; Wang et al., 2010).

The change in the surface latent heat flux is quite similar to the prediction by Miller et al. (2004b). The instantaneous latent heat flux decreases over the study region with a domain average value of $-1 \mathrm{Wm}^{-2}$ in the presence of dust aerosols over land. Figure $15 \mathrm{c}$ shows the decrease in the instantaneous sensible heat flux over land due to dust aerosols with a domain average value of $-23.6 \mathrm{~W} \mathrm{~m}^{-2}$. The daytime cooling at the surface leads to reductions in the upward transport of heat from the surface to the atmosphere. The decreases in surface latent heat and sensible heat fluxes caused by dust aerosols have been reported previously by Yue et al. (2010), Miller et al. (2004b), and Shell and Somerville (2007).

\section{Summary and conclusions}

A severe dust storm from 18 to 22 March 2012 was simulated using WRF-Chem to account for interactive dust generation and radiative effects. The model is able to simulate the major spatial features of meteorological fields in the study domain reasonably well. The synoptic systems that generated these dust events were associated with a fast-moving cold front accompanied by a high-level trough. Strong wind (velocities exceeding $15 \mathrm{~m} \mathrm{~s}^{-1}$ ) occurred behind the cold front, which entrained large quantities of dust particles into the atmosphere. The meteorological conditions that led to strong winds capable of producing the severe dust event have been identified. There were several rich dust source areas in the region, activated by the passage of the front, where the major plumes of dust storm originated. The simulation suggests that the main dust sources during the dust storm include river valleys of the lower Tigris and Euphrates in Iraq, areas from Kuwait, Iran, UAE, and the major Arabian deserts, Rub' al Khali, An Nafud, and Ad Dahna. Dust sources were also identified along the western coast of the Arabian Peninsula. 
Our calculations show that $94 \mathrm{Mt}$ of dust was emitted into the atmosphere during the simulation period. Approximately $78 \%(73 \mathrm{Mt})$ of the dust was deposited back to the study domain and $22 \%$ (i.e., $21 \mathrm{Mt}$ ) were transported outside the model domain. Approximately $6.5 \mathrm{Mt}$ of dust was deposited to the oceans within the model domain. The Red Sea received 1.2 Mt of dust during this event. Dust particles bring nutrients to marine ecosystems; by scaling the effect of one storm to the number of dust storms observed annually over the Red Sea, we estimate the annual dust deposition, associated with dust storms, to be $6 \mathrm{Mt}$.

The variation in terrain elevation and surface properties produces large variability in the PBL depth over the Arabian Peninsula. The deepest PBLs developed over the higher elevations of the western Arabian Peninsula and over desert areas. The model predicted a well-mixed, deep boundary layer up to a height of about $3.5 \mathrm{~km}$ in the afternoon. Over land, approximately $15 \%$ of dust was entrained in the free troposphere, while over the seas it might be more than $50 \%$. This is extremely important for understanding the dynamics and long-range transport of dust plumes.

The modeled AOD compares well with AERONET at the three sites and with satellite data. The simulation shows that mineral dust heats the lower atmosphere (1-3 km) by SW absorption with a maximum rate up to $9 \mathrm{~K} \mathrm{day}^{-1}$ over Mezaira at 12:00 UTC on 19 March. The lower atmospheric heating is also reflected by the temperature inversions observed in the RS temperature profiles. The meteorological responses to the dust radiative effects indicate a cooling at the surface over the high dust concentration regions. The daily domain average values of the net dust DRE at the surface and TOA under clear sky conditions at the time of the dust storm on 19 March are $-10 \mathrm{~W} \mathrm{~m}^{-2}$ and $-4 \mathrm{~W} \mathrm{~m}^{-2}$, respectively. The SW DRE is negative at the surface over the domain with a largest daily average value of $-134 \mathrm{~W} \mathrm{~m}^{-2}$ and a domain-averaged value of $-16 \mathrm{Wm}^{-2}$. The daily average SW DRE at TOA is positive $\left(\sim 10 \mathrm{~W} \mathrm{~m}^{-2}\right)$ over high albedo deserts and negative over oceans due to the smaller surface albedo. The maximum daily averaged LW DRE at the surface is $43 \mathrm{Wm}^{-2}$ with a domain average value of $6 \mathrm{~W} \mathrm{~m}^{-2}$. At TOA, the maximum daily average value of LW DRE is $8.40 \mathrm{~W} \mathrm{~m}^{-2}$ with a domain-averaged value of $0.25 \mathrm{~W} \mathrm{~m}^{-2}$. At the surface, the SW DRE always leads to cooling and LW DRE to heating. The dust radiative effects cause maximum change in the surface air temperature up to $-6.70 \mathrm{~K}$ and with a domainaveraged value of $-0.26 \mathrm{~K}$ at $12: 00 \mathrm{UTC}$ on $19 \mathrm{March}$. The change in the surface air temperature in the model is a combined effect of the SW and LW DRE. The indirect effect of mineral dust is not implemented in the model for the present study. The changes in domain average values of latent and sensible heat flux are -1 and $-23.60 \mathrm{~W} \mathrm{~m}^{-2}$, respectively.
Acknowledgements. The authors would like to thank A. Al Suwailem of KAUST for help in establishing a permanent AERONET site at the King Abdullah University of Science and Technology. We thank Hala Al-Jassar, a principal investigator of the AERONET site at Kuwait University, and Brent Holben of NASA Goddard Space Flight Center, who maintains the entire AERONET operations, for making available AERONET data used in this study. Research reported in this publication was supported by the King Abdullah University of Science and Technology. For computer time, this research used the resources of the KAUST supercomputing laboratory.

Edited by: C. McNeil

\section{References}

Ackerman, S. A.: Remote sensing of aerosol using satellite infrared observations, J. Geophys. Res., 102, 17069-17079, 1997.

Ackerman, S. A. and Chung, H.: Radiative effects of airborne dust on regional energy budgets at the top of the atmosphere, J. Appl. Meteor., 31, 223-233, doi:10.1175/15200450(1992)031<0223:REOADO>2.0.CO;2, 1992.

Ackermann, I. J., Hass, H., Memmsheimer, M., Ebel, A., Binkowski, F. S., and Shankar, U.: Modal aerosol dynamics model for Europe: development and first applications, Atmos. Environ., 32, 2981-2999, doi:10.1016/S1352-2310(98)00006-5, 1998.

Ahn, H. J., Park, S. U., and Chang, L. S.: Effect of direct radiative forcing of Asian dust on the meteorological fields in East Asia during an Asian dust event period, J. Appl. Meteorol. Clim., 46, 1655-1681, doi:10.1175/JAM2551.1, 2007.

Albrecht, B. A.: Aerosols, cloud microphysics, and fractional cloudiness, Science, 245, 1227-1230, 1989.

Alpert, P., Kaufman, Y. J., Shay-El, Y., Tanre, D., Silva, A. D., Schubert, S., and Joseph, J. H.: Quantification of dustforced heating of the lower troposphere, Nature, 395, 367-370, doi:10.1038/26456, 1998.

Aminou, D., Jacquet, B., and Pasternak, F.: Characteristics of the Meteosat Second Generation Radiometer/Imager SEVIRI, Proceedings of SPIE Europto Series, 3221, 19-31, 2002.

Andreas, M. O.: Raising dust in the greenhouse, Nature, 380, 389390, 1996.

Ansmann, A., Petzold, A., Kandler, K., Tegen, I., Wendisch, M., Muller, D., Weinzierl, B., Muller, T., and Heintzenberg, J.: Saharan mineral dust experiments SAMUM-1 and SAMUM-2: what have we learned?, Tellus B, 63, 403-429, doi:10.1111/j.16000889.2011.00555.x, 2011.

Arimoto, R., Duce, R. A., and Ray, B. R.: Concentrations, sources and air-sea exchange of trace elements in the atmosphere over the Pacific Ocean, in: Chemical Oceanography, 10, edited by: Riley, J. P., Chester, R. and Duce, R. A., Academic Press, San Diego, 107-149, 1989.

Bader, D. C. and McKee, T. B.: Dynamical model simulation of the morning boundary layer development in deep mountain valleys, J. Clim. Appl. Meteorol., 22, 341-351, 1983.

Balkanski, Y., Schulz, M., Claquin, T., and Guibert, S.: Reevaluation of Mineral aerosol radiative forcings suggests a better agree- 
ment with satellite and AERONET data, Atmos. Chem. Phys., 7, 81-95, doi:10.5194/acp-7-81-2007, 2007.

Barkan, J., Kutiel, H., and Alpert, P.: Climatology of dust sources in North Africa and the Arabian Peninsula based on TOMS data, Indoor Built Environ., 13, 407-419, 2004.

Bennett, C. M., McKendry, I. G., Kelly, S., Denike, K., and Koch, T.: Impact of the 1998 Gobi dust event on hospital admissions in the Lower Fraser Valley, British Columbia, Sci. Total Environ., 366, 918-925, 2006.

Bennion, P., Hubbard, R., O'Hara, S., Wiggs, G., Wegerdt, J., Lewis, S., Small, I., van der Meer, J., and Upshur, R.: The impact of airborne dust on respiratory health in children living in the Aral Sea region, Int. J. Epidemiol., 36, 1103-1110, 2007.

Buseck, P. R. and Posfai, M.: Airborne minerals and related aerosol particles: effects on climate and the environment, P. Natl. Acad. Sci. USA, 96, 3372-3379, 1999.

Carlson, T. N. and Benjamin, S.: Radiative heating rates for Sahara dust, J. Atmos. Sci., 37, 193-197, 1980.

Carolina, C. G. and Martin, C. T.: Model simulations of complex dust emissions over the Sahara during the West African monsoon onset, Adv. Meteor., 351731, 1-17, doi:10.1155/2012/351731, 2012.

Cautenet, G., Legrand, M., Cautenet, S., Bonnel, B., and Brogniez, G.: Thermal impact of Saharan dust over land. Part I: Simulation, J. Appl. Meteorol., 31, 166-180, doi:10.1175/15200450(1992)031<0166:TIOSDO>2.0.CO;2, 1991.

Chaboureau, J. P., Tulet, P., and Mari, C.: Diurnal cycle of dust and cirrus over West Africa as seen from Meteosat Second Generation satellite and a regional forecast model, Geophys. Res. Lett., 34, L02822, doi:10.1029/2006GL027771, 2007.

Chen, F. and Dudhia, J.: Coupling an advanced land surface/hydrology model with the Penn State/NCAR MM5 modeling system. Part I: Model description and implementation, Mon. Weather Rev., 129, 569-585, 2001.

Chen, S., Kuo, Y. Ming, W., and Ying, H.: The effect of dust radiative heating on low-level frontogenesis, J. Atmos. Sci., 52, 14141420, 1994.

Chin, M., Ginoux, P., Kinne, S., Torres, O., Holben, B. N., Duncan, B. N., Martin, R. V., Logan, J. A., Higurashi, A., and Nakajima, T.: Tropospheric aerosol optical thickness from the GOCART model and comparisons with satellite and sun photometer measurements, J. Atmos. Sci., 59, 461-483, 2002.

Chylek, P. and Wong, J.: Effect of absorbing aerosols on global radiation budget, Geophys. Res. Lett., 22, 929-931, 1995.

Claquin, T., Schulz, M., Balkanski, Y., and Boucher, O.: Uncertainties in assessing radiative forcing by mineral dust, Tellus B, 50, 491-505, 1998

Cuesta, J., Marsham, J. H., Parker, D. J., and Flamant, C.: Dynamical mechanisms controlling the vertical redistribution of dust and the thermodynamic structure of the West Saharan atmospheric boundary layer during summer, Atmos. Sci. Lett., 10, 34-42, doi:10.1002/asl.207, 2009.

Chung, Y. S. and Yoon, M. B.: On the occurrence of yellow sand and atmospheric loadings, Atmos. Environ., 3013, 2387-2397, 1996.

Dayan, U., Heffter, J., Miller, J., and Gutman, G.: Dust intrusion events into the Mediterranean Basin, J. Appl. Meteorol., 30, 1185-1199, 1991.
Dee, D. P., Uppala, S. M., Simmons, A. J., Berrisford, P., Poli, P., Kobayashi, S., Andrae, U., Balmaseda, M. A., Balsamo, G., Bauer, P., Bechtold, P., Beljaars, A. C. M., van de Berg, L., Bidlot, J., Bormann, N., Delsol, C., Dragani, R., Fuentes, M., Geer, A. J., Haimberger, L., Healy, S. B., Hersbach, H., Hólm, E. V., Isaksen, L., Kållberg, P., Köhler, M., Matricardi, M., McNally, A. P., MongeSanz, B. M., Morcrette, J. J., Park, B. K., Peubey, C., de Rosnay, P., Tavolato, C., Thépaut, J. N., Vitart, F.: The ERAInterim reanalysis: configuration and performance of the data assimilation system, Q. J. Roy. Meteor. Soc., 137, 553-597, doi:10.1002/qj.828, 2011.

Eck, T. F., Holben, B. N., Reid, J. S., Dubovik, O., Smirnov, A., O'Neill, N. T., Slutsker, I., and Kinne, S.: Wavelength dependence of the optical depth of biomass burning, urban and desert dust aerosols, J. Geophys. Res., 104, 31333-31350, 1999.

Engelstaedter, S., Tegen, I., and Washington, R.: North African dust emissions and transport, Earth-Sci. Rev., 79, 73-100, 2006.

Fan, S., Moxim, M., and Levy II, H.: Aeolian input of bioavailable iron to the ocean, Geophys. Res. Lett., 33, L07602, doi:10.1029/2005GL024852, 2006.

Forster, P., Ramaswamy, V., Artaxo, P., Berntsen, T., Betts, R., Fahey, D. W., Haywood, J., Lean, J., Lowe, D. C., Myhre, G., Nganga, J., Prinn, R., Raga, G., Schulz, M., and Van Dorland, R.: Changes in atmospheric constituents and in radiative forcing, in: Climate Change 2007: The Physical Science Basis, Working Group I to the Fourth Assessment Report of the Intergovernmental Panel on Climate Change, EDITED BY: Solomon, S., Qin, D., Manning, M., Chen, Z., Marquis, M., Averyt, K. B., Tignor, M., and Miller, H. L., Cambridge Univ. Press, Cambridge, UK, 129234, 2007.

Fryrear, D. W.: Long-term effect of erosion and cropping on soil productivity, Geol. S. Am. S., 186, 253-259, 1981.

Gamo, M.: Thickness of the dry convection and large-scale subsidence above deserts, Bound.-Lay. Meteorol., 79, 265-278, 1996.

Gillette, D.: A wind tunnel simulation of the erosion of soil: effect of soil texture, sand-blasting, wind speed, and soil consolidation on the dust production, Atmos. Environ., 12, 1735-1743, 1978.

Gillette, D. A. and Hanson, K. J.: Spatial and temporal variability of dust production caused by wind erosion in the United States, J. Geophys. Res., 94, 2197-2206, 1989.

Ginoux, P., Chin, M., Tegen, I., Prospero, J. M., Holben, B., Dubovik, O., and Lin, S. J.: Sources and distributions of dust aerosols simulated with the GOCART model, J. Geophys. Res., 106, 20255-20273, 2001.

Goudie, A. S. and Middleton, N. J.: Desert Dust in the Global System, Springer, Heidelberg, 2006.

Grell, G. A. and Devenyi, D.: A generalized approach to parameterizing convection combining ensemble and data assimilation techniques, Geophys. Res. Lett., 29, 1693, doi:10.1029/2002GL015311, 2002.

Grell, G. A., Peckham, S. E., Schmitz, R., McKeen, S. A., Frost, G., Skamarock, W. C., and Eder, B.: Fully coupled online chemistry within the WRF model, Atmos. Environ., 39, 6957-6975, 2005.

Hagen, L. J. and Woodruff, N. P.: Air pollution from dust storms in the Great Plains, Atmos. Environ., 7, 323-332, 1973.

Hamidi, M., Kavianpour, M. R., and Shao, Y.: Synoptic analysis of dust storms in the Middle Est, Asia Pac. J. Atmos. Sci., 49, 279-286, doi:10.1007/s13143-013-0027-9, 2013. 
Han, Z., Li, J., Guo, W., Xiong, Z., and Zhang, W.: A study of dust radiative feedback on dust cycle and meteorology over East Asia by a coupled regional climate-chemistry-aerosol model, Atmos. Environ., 68, 54-63, 2013.

Harrison, S. P., Kohfeld, K. E., Roelandt, C., and Claquin, T.: The role of dust in climate changes today, at the last glacial maximum and in the future, Earth-Sci. Rev., 54, 43-80, 2001.

Haywood, J. and Boucher, O.: Estimates of the direct and indirect radiative forcing due to tropospheric aerosols: a review, Rev. Geophys., 38, 513-543, 2000.

Haywood, J. M., Francis, P. N., Glew, M. D., and Taylor, J. P.: Optical properties and direct radiative effect of Saharan dust: a case study of two Saharan dust outbreaks using aircraft data, J. Geophys. Res.-Atmos., 106, 18417-18430, 2001.

Haywood, J., Francis, P., Osborne, S., Glew, M., Loeb, N., Highwood, E., Tanre, D., Myhre, G., Formenti, P., and Hirst, E.: Radiative properties and direct radiative effect of Saharan dust measured by the C-130 aircraft during SHADE: 1. Solar spectrum, J. Geophys. Res., 108, 8577, doi:10.1029/2002JD002687, 2003.

Haywood, J. M., Allan, R. P., Culverwell, I., Slingo, T., Milton, S., Edwards, J., and Clerbaux, N.: Can desert dust explain the outgoing longwave radiation anomaly over the Sahara during July 2003, J. Geophys. Res., 110, D05105, doi:10.1029/2004JD005232, 2005.

Heinold, B., Tegen, I., Schepanski, K., and Hellmuth, O.: Dust radiative feedback on Saharan boundary layer dynamics and dust mobilization, Geophys. Res. Lett., 35, L20817, doi:10.1029/2008GL035319, 2008.

Heinold, B., Tegen, I., Esselborn, M., Kandler, K., Knippertz, P., Müller, D., Schladitz, A., Tesche, M., Weinzierl, B., Ansmann, A., Althausen, D., Laurent, B., Massling, A., Müller, T., Petzold, A., Schepanski, K., and Wiedensohler, A.: Regional Saharan dust modelling during the SAMUM 2006 campaign, Tellus B, 61, 307-324, doi:10.1111/j.1600-0889.2008.00387.x, 2009.

Heinold, B., Tegen, I., Bauer, S., and Wendisch, M.: Regional modelling of Saharan dust and biomass burning smoke, Part 2: Direct radiative forcing and atmospheric dynamic response, Tellus $\mathrm{B}$, 63, 800-813, doi:10.1111/j.1600-0889.2011.00574.x, 2011a.

Heinold, B., Tegen, I., Schepanski, K., Tesche, M., Esselborn, M., Freudenthaler, V., Gross, S., Kandler, K., Knippertz, P., Müller, D., Schladitz, A., Toledano, C., Weinzierl, B., Ansmann, A., Althausen, D., Müller, T., Petzold, A., and Wiedensohler, A.: Regional modelling of Saharan dust and biomassburning smoke, Tellus B, 63, 781-799, doi:10.1111/j.16000889.2011.00570.x, 2011b.

Heintzenberg, J.: The SAMUM-1 experiment over southern Morocco: overview and introduction, Tellus B, 61, 2-11, doi:10.1111/j.1600-0889.2008.00403.x, 2009.

Holben, B. N., Eck, T. F., Slutsker, I., Tanre, D., Buis, J. P., Setzer, A., Vermote, E., Reagan, J. A., Kaufman, Y. J., Nakajima, T., Lavenu, F., Jankowiak, F., and Smirnov, A.: AERONET - a federated instrument network and data archive for aerosol characterization, Remote Sens. Environ., 66, 1-16, 1998.

Hsu, N. C., Tsay, S. C., King, M. D., and Herman, J. R.: Aerosol properties over bright-reflecting source regions, IEEE T. Geosci. Remote, 42, 557-569, doi:10.1109/TGRS.2004.824067, 2004.

Hsu, N. C., Tsay, S., King, M. D., and Herman, J. R.: Deep blue retrievals of Asian aerosol properties dur- ing ACE-Asia, IEEE T. Geosci. Remote, 44, 3180-3195, doi:10.1109/TGRS.2006.879540, 2006.

Huang, J., Fu, Q., Su, J., Tang, Q., Minnis, P., Hu, Y., Yi, Y., and Zhao, Q.: Taklimakan dust aerosol radiative heating derived from CALIPSO observations using the Fu-Liou radiation model with CERES constraints, Atmos. Chem. Phys., 9, 4011-4021, doi:10.5194/acp-9-4011-2009, 2009.

Husar, R. B., Tratt, D. M., Schichtel, B. A., Falke, S. R., Li, F., Jaffe, D., Gassó, S., Gill, T., Laulainen, N. S., Lu, F., Reheis, M. C., Chun, Y., Westphal, D., Holben, B. N., Gueymard, C., McKendry, I., Kuring, N., Feldman, G. C., McClain, C., Frouin, R. J., Merrill, J., DuBois, D., Vignola, F., Murayama, T., Nickovic, S., Wilson, W. E., Sassen, K., Sugimoto, N., and Malm, W. C.: Asian dust events of April 1998, J. Geophys. Res., 106, 18317-18330, 2001.

Janjic, Z. I.: Nonsingular Implementation of the Mellor-Yamada Level 2.5 Scheme in the NCEP Meso model, NCEP Office Note, 437, available at: http://www.emc.ncep.noaa.gov/ officenotes/newernotes/on437.pdf (last access: January 2014), 2001.

Jayaraman, A., Lubin, D., Ramachandran, S., Ramanathan, V., Woodbridge, E., Collins, W. D., and Zalpuri, K. S.: Direct observations of aerosol radiative forcing over the tropical Indian Ocean during the January-February 1996 pre-INDOEX cruise, J. Geophys. Res., 103, 13827-13836, 1998.

Jauregui, E.: The dust storms of Mexico City, Int. J. Climatol., 9, 169-180, 1989.

Joussaume, S.: Three-dimensional simulation of the atmospheric cycle of desert dust particles using a general circulation model, J. Geophys. Res., 95, 1909-1941, 1990.

Kalenderski, S., Stenchikov, G., and Zhao, C.: Modeling a typical winter-time dust event over the Arabian Peninsula and the Red Sea, Atmos. Chem. Phys., 13, 1999-2014, doi:10.5194/acp-131999-2013, 2013.

Karyampudi, V. M. and Carlson, T. N.: Analysis and numerical simulations of the Saharan air layer and its effect on easterly wave disturbances, J. Atmos. Sci., 45, 3102-3136, doi:10.1175/15200469(1988)045<3102:AANSOT>2.0.CO;2, 1988.

Kaskaoutis, D. G., Kambezidis, H. D., Nastos, P. T., and Kosmopoulos, P. G.: Study on an intense dust storm over Greece, Atmos. Environ., 42, 6884-6896, 2008.

Kimura, F. and Kuwagata, T.: Horizontal heat fluxes over complex terrain computed using a simple mixed-layer model and a numerical model, J. Appl. Meteorol., 34, 549-558, 1995.

Kutiel, H. H. F.: Dust Storms in the Middle East: sources of origin and their temporal characteristics, Indoor Built Environ., 12, 419-426, 2003.

Kuwagata, T. and Kimura, F.: Daytime boundary layer evolution in a deep valley. Part I: Observations in the Ina Valley, J. Appl. Meteorol., 34, 1082-1091, 1995.

Laurent, B., Marticorena, B., Bergametti, G., Le'on, J. F., and Mahowald, N. M.: Modeling mineral dust emissions from the Sahara desert using new surface properties and soil database, J. Geophys. Res., 113, D14218, doi:10.1029/2007JD009484, 2008.

Laurent, B., Tegen, I., Heinold, B., Schepanski, K., Weinzierl, B., and Esselborn, M.: A model study of Saharan dust emissions and distributions during SAMUM-1 campaign, J. Geophys. Res. 115, D21210, doi:10.1029/2009JD012995, 2010. 
Lemaître, C., Flamant, C., Cuesta, J., Raut, J.-C., Chazette, P., Formenti, P., and Pelon, J.: Radiative heating rates profiles associated with a springtime case of Bodélé and Sudan dust transport over West Africa, Atmos. Chem. Phys., 10, 8131-8150, doi:10.5194/acp-10-8131-2010, 2010.

Liao, H. and Seinfeld, J. H.: Radiativeforcing by mineral dust aerosols: sensitivity to key variables, J. Geophys. Res., 103, 31637-31645, 1998a.

Liao, H. and Seinfeld, J. H.: Effect of clouds on direct aerosol radiative forcing of climate, J. Geophys. Res., 103, 3781-3788, 1998 b.

Liao, H., Seinfeld, J. H., Adams, P. J., and Mickley, L. J.: Global radiative forcing of coupled tropospheric ozone and aerosols in a unified general circulation model, J. Geophys. Res., 109, D16207, doi:10.1029/2003JD004456, 2004.

Lin, Y. L., Farley, R. D., and Orville, H. D.: Bulk parameterization of the snow field in a cloud model, J. Clim. Appl. Meteorol., 22, 1065-1092, 1983.

Liu, C. M. and Ou, S. S.: Effects of tropospheric aerosols on the solar radiative heating in a clear atmosphere, 1990, Theor. Appl. Climatol., 41, 97-106, 1990.

Longstreth, J. D., de Gruijl, F. R., Kripke, M. L., Takizawa, Y., and van der Leun, J. C.: Effects of increased solar ultraviolet radiation on human health, Ambio, 24, 153-165, 1995.

Lu, H. and Shao, Y.: Toward quantitative prediction of dust storms: an integrated wind erosion modeling system and its applications, Environ. Modell. Softw., 16, 233-249, 2001.

Markowicz, K. M., Flatau, P. J., Vogelmann, A. M., Quinn, P. K., and Welton, E. J.: Clear-sky infrared aerosol radiative forcing at the surface and the top of the atmosphere, Q. J. Roy. Meteor. Soc., 129, 2927-2947, doi:10.1256/qj.02.224, 2003.

Martin, J. M.: Glacial-interglacial $\mathrm{CO}_{2}$ change: the iron hypothesis, Paleoceanography, 5, 1-13, 1990.

McFarlane, S, A., Kassianov, E. I., Barnard, J., Flynn, C., and Ackerman, T. P.: Surface shortwave aerosol radiative forcing during the atmospheric radiation measurement mobile facility deployment in Niamey, Niger, J. Geophys. Res., 114, D00E06, doi:10.1029/2008JD010491, 2009.

McKendry, I. G., Hacker, J. P., Stull, R., Sakiyama, S., Mignacca, D., and Reid, K.: Long-range transport of Asian dust to the Lower Fraser Valley, British Columbia, Canada, J. Geophys. Res., 106, 18361-18370, 2001.

Michalakes, J., Duhia, D., Gill, D., Henderson, T., Klemp, J., and Wang, W.: The weather research and forecast model: software architecture and performance, in: Proceedings of the 11th ECMWF Workshop on the Use of High Performance Computing in Meteorology, edited by: Zwieflhofer, W. and Mozdzynski, G., World Scientific, Singapore, 156-168, 2005.

Middleton, N. J.: Dust storms in the Middle East, J. Arid Environ., 10, 83-96, 1986a.

Middleton, N. J.: A geography of dust storms in south-west Asia, J. Climatol., 6, 183-196, 1986b.

Middleton N. J. and Chaudhary Q. Z.: Severe dust storm at Karachi, 31 May 1986, Weather, 438, 298-301, 1988.

Miller, R. L. and Tegen, I.: Climate response to soil dust aerosols, J. Climate, 11, 3247-3267, doi:10.1175/15200442(1998)011<3247:CRTSDA>2.0.CO;2, 1998.

Miller, R. L., Perlwitz, J., and Tegen, I.: Feedback upon dust emission by dust radiative forcing through the plan- etary boundary layer, J. Geophys. Res., 109, D24209, doi:10.1029/2004JD004912, 2004a.

Miller, R. L., Tegen, I., and Perlwitz, J.: Surface radiative forcing by soil dust aerosols and the hydrologic cycle, J. Geophys. Res., 109, D04203, doi:10.1029/2003JD004085, 2004b.

Mitchell, J. M.: The effect of atmospheric particles on radiation and temperature, in: Man's Inspection on the Climate, edited by: Mathews W. H., Kellogg W. W. and Robinson G. D., MIT Press, Cambridge, 295-301, 1971.

Mohalfi, S., Bedi, H. S., Krishnamurti, T. N., and Cocke, S. D.: Impact of shortwave radiative effects of dust aerosols on the summer season heat low over Saudi Arabia, Mon. Weather Rev., 126, 3153-3168, 1998.

Morales, C.: Saharan Dust, Scope 14, John Wiley \& Sons, New York, 297, 1979.

Nickovic, S., Kallos, S., Papadopoulos, A., and Kakaliagou, O.: A model for prediction of desert dust cycle in the atmosphere, J. Geophys. Res., 106, 18113-18129, 2001.

Nihlen, T. and Lund, S. O.: Influence of aeolian dust on soil formation in the Aegean area, Z. Geomorphol., 393, 341-361, 1995.

Notaro, M., Alkolibi, F., Fadda, E., and Bakhrjy, F.: Trajectory analysis of Saudi Arabian dust storms, J. Geophys. Res.-Atmos., 118, 6028-6043, doi:10.1002/jgrd.50346, 2013.

N'Tchayi Mbourou G., Bertrand J. J., and Nicholson S. E.: The diurnal and seasonal cycles of wind-borne dust over Africa north of the equator, J. Appl. Meteorol., 36, 868-882, 1997.

NOAA (National Oceanographic and Atmospheric Agency): Dust storms, sand storms and related NOAA activities in the Middle East, NOAA Magazine, 86, 1-5, 2002.

Perez, C., Nickovic, S., Pejanovic, G., Baldasano, J. M., and Ozsoy, E.: Interactive dust-radiation modeling: A step to improve weather forecasts, J. Geophys. Res., 111, D16206, doi:10.1029/2005JD006717, 2006.

Prospero, J. M., Nees, R. T., and Uematsu, M.: Deposition rate of particulate and dissolved aluminum derived from Saharan dust in precipitation at Miami, Florida, J. Geophys. Res., 92, 1472314731, 1987.

Prospero, J. M., Ginoux, P., Torres, O., Nicholson, S. E., and Gill, T. E.: Environmental characterization of global sources of atmospheric soil dust identified with the Nimbus 7 Total Ozone Mapping Spectrometer (TOMS) absorbing aerosol product, Rev. Geophys., 40, 1002, doi:10.1029/2000RG000095, 2002.

Pye, K.: Aeolian Dust and Dust Deposits, Academic Press, London, 334, 1987.

Reid, J. S. and Maring, H. B.: Foreword to special section on the Puerto Rico Dust Experiment (PRIDE), J. Geophys. Res.Atmos., 108, 8585, doi:10.1029/2003jd003510, 2003.

Reid, J. S., Piketh, S. J., Walker, A. L., Burger, R. P., Ross, K. E., Westphal, D. L., Bruintjes, R. T., Holben, B. H., Hsu, C., Jensen, T. L., Kahn, R. A., Kuciauskas, A. P., Mandoos, A. A., Mangoosh, A., Miller, S. D., Porter, J. N., Reid, E. A., and Tsay, S. C.: An overview of UAE2 flight operations: observations of summertime atmospheric thermodynamic and aerosol profiles of the southern Arabian Gulf, J. Geophys. Res., 113, D14213, doi:10.1029/2007JD009435, 2008.

Remer, L. A., Kaufman, Y. J., Tanré, D., Mattoo, S., Chu, D. A., Martins, J. V., Li, R. R., Ichoku, C., Levy, R. C., Kleidman, R. G., Eck, T. F., Ver- 
mote, E., and Holben, B. N.: The MODIS aerosol algorithm, products and validation, J. Atmos. Sci., 62, 947-973, 2005.

Remer, L. A., Kleidman, R. G., Levy, R. C., Kaufman, Y. J., Tanre, D., Mattoo, S., Martins, J. V., Ichoku, C., Koren, I., Yu, H., and Holben, B. N.: Global aerosol climatology from the MODIS satellite sensors, J. Geophys. Res., 113, D14S07, doi:10.1029/2007JD009661, 2008.

Rezazadeh, M., Irannejad, P., and Shao, Y.: Climatology of the Middle East dust events, Aeolian Res., 10, 103-109, 2013.

Salomonson, V., Barnes, W., Maymon, P., Montgomery, H., and Ostrow, H.: MODIS: advanced facility instrument for studies of the Earth as a system, IEEE T. Geosci. Remote, 27, 145-153, 1989.

Satheesh, S. K. and Ramanathan, V.: Large differences in tropical aerosol forcing at the top of the atmosphere and Earth's surface, Nature, 405, 60-63, 2000.

Satheesh, S. K., Krishna Moorthy, K., Kaufman, Y. J. and Takemura, T.: Aerosol optical depth, physical properties and radiative forcing over the Arabian Sea, Meteorol. Atmos. Phys., 91, 4562, doi:10.1007/s00703-004-0097-4, 2006.

Schell, B., Ackermann, I. J., Hass, H., Binkowski, F. S., and Ebel, A.: Modeling the formation of secondary organic aerosol within a comprehensive air quality model system, J. Geophys. Res., 106, 28275-28293, doi:10.1029/2001JD000384, 2001.

Shao, Y.: Physics and Modelling of Wind Erosion, Springer, 34-35, 37, ISBN 1402088957, 9781402088957, 2008.

Shao, Y., Yang, Y., Wang, J., Song, Z., Leslie, L. M., Dong, C., Zhang, Z., Lin, Z., Kanai, Y., Yabuki, S., and Chun, Y.: Northeast Asian dust storms: real-time numerical prediction and validation, J. Geophys. Res., 108, 4691, doi:10.1029/2003JD003667, 2003.

Shao, Y. P., Wyrwoll, K. H., Chappell, A., Huang, J. P., Lin, Z. H., McTainsh, G. H., Mikami, M., Tanaka, T. Y., Wang, X. L., and Yoon, S.: Dust cycle: an emerging core theme in Earth system science, Aeolian Res., 2, 181-204, doi:10.1016/j.aeolia.2011.02.001, 2011.

Shell, K. M. and Somerville, R. C. J.: Direct radiative effect of mineral dust and volcanic aerosols in a simple aerosol climate model, J. Geophys. Res., 112, D03206, doi:10.1029/2006JD007198, 2007.

Sissakian, V., Al-Ansari, N., and Knutsson, S.: Sand and duststorm events in Iraq, Natural Science, 5, 1084-1094, doi:10.4236/ns.2013.510133, 2013.

Skamarock, W. C., Klemp, J. B., Dudhia, J., Gill, D. O., Barker, D. M., Wang, W., and Powers, J. G.: A Description of the Advanced Research WRF Version 2, NCAR Tech. Note, NCAR/TN-468+STR, NCAR, Boulder, available at: http: //wrf-model.org/wrfadmin/publications.php (last access: January 2014), 2008.

Sokolik, I. N. and Golitsyn, G.: Investigation of optical and radiative properties of atmospheric dust aerosols, Atmos. Environ., 27, 2509-2517, 1993.

Sokolik, I. N. and Toon, O. B.: Direct radiative forcing by anthropogenic airborne mineral aerosols, Nature, 381, 681-683, 1996.

Sokolik I. N., Toon, O. B., and Bergstrom, R. W.: Modeling the radiative characteristics of airborne mineral aerosols at infrared wavelengths, J. Geophys. Res., 103, 8813-8826, 1998.

Sokolik, I. N., Winker, D. M., Bergametti, G., Gillette, D. A., Carmichael, G., Kaufman, Y. J., Gomes, L., Schuetz, L., and Penner, J. E.: Introduction to special section: outstanding problems in quantifying the radiative impacts of mineral dust, J. Geophys. Res., 106, 18015-18027, 2001.

Stenchikov, G. L., Kirchner, I., Robock, A., Graf, H. F., Antuña, J. C., Grainger, R. G., Lambert, A., and Thompson, L.: Radiative forcing from the 1991 Mount Pinatubo volcanic eruption, J. Geophys. Res. 103, 13837-13857, 1998.

Stier, P., Seinfeld, J. H., Kinne, S., and Boucher, O.: Aerosol absorption and radiative forcing, Atmos. Chem. Phys., 7, 5237-5261, doi:10.5194/acp-7-5237-2007, 2007.

Stockwell, W. R., Middleton, P., Chang, J. S., and Tang, X.: The second generation regional acid deposition model chemical mechanism for regional air quality modeling, J. Geophys. Res., 95, 16343-16367, doi:10.1029/JD095iD10p16343, 1990.

Sunda, W. G. and Huntsman, S. A.: Interrelated influence of iron, light and cell size on marine phytoplankton growth, Nature, 390, 389-392, 1997.

Swap, R., Ulanski, S., Cobbett, M., and Garstang, M.: Temporal and spatial characteristics of Saharan dust outbreaks, J. Geophys. Res., 101, 4205-4220, 1996.

Talbot, R. W., Harriss, R. C., Browell, E. V., Gregory, G. L., Sebacher, D. I., and Beck, S. M.: Distribution and geochemistry of aerosols in the tropical North Atlantic troposhere: relationship to Saharan dust, J. Geophys. Res., 91, 5173-5182, 1986.

Tegen, I. and Fung, I.: Modeling of mineral dust in the atmosphere: sources, transport and optical thickness, J. Geophys. Res., 99 22897-22914, 1994.

Tegen, I. and Fung, I.: Contribution to the atmospheric mineral aerosol load from land surface modification, J. Geophys. Res., 100, 18707-18726, 1995.

Tegen, I. and Lacis, A. A.: Modelingof particlesize distribution and its influence on the radiative properties of mineral dust aerosol, J. Geophys. Res., 101, 19237-19244, 1996.

Tegen, I., Lacis, A. A., and Fung, I.: The influence on climate forcing of mineral aerosols from disturbed soils, Nature, 380, 419422, 1996.

Tegen, I., Bierwirth, E., Heinold, B., Helmert, J., and Wendisch, M.: Effect of measured surface albedo on modeled Saharan dust solar radiative forcing, J. Geophys. Res., 115, D24312, doi:10.1029/2009JD013764, 2010.

Tegen, I., Schepanski, K., and Heinold, B.: Comparing two years of Saharan dust source activation obtained by regional modelling and satellite observations, Atmos. Chem. Phys., 13, 2381-2390, doi:10.5194/acp-13-2381-2013, 2013.

Textor, C., Schulz, M., Guibert, S., Kinne, S., Balkanski, Y., Bauer, S., Berntsen, T., Berglen, T., Boucher, O., Chin, M., Dentener, F., Diehl, T., Easter, R., Feichter, H., Fillmore, D., Ghan, S., Ginoux, P., Gong, S., Grini, A., Hendricks, J., Horowitz, L., Huang, P., Isaksen, I., Iversen, I., Kloster, S., Koch, D., Kirkevåg, A., Kristjansson, J. E., Krol, M., Lauer, A., Lamarque, J. F., Liu, X., Montanaro, V., Myhre, G., Penner, J., Pitari, G., Reddy, S., Seland, Ø., Stier, P., Takemura, T., and Tie, X.: Analysis and quantification of the diversities of aerosol life cycles within AeroCom, Atmos. Chem. Phys., 6, 1777-1813, doi:10.5194/acp-6-1777-2006, 2006.

Tratt, D. M., Frouin, R. J., and Westphal, D. L.: April 1998 Asian dust event: a southern California perspective, J. Geophys. Res., 106, 18371-18379, 2001.

Twomey, S.: The influence of pollution on the shortwave albedo of clouds, J. Atmos. Sci., 34, 1149-1152, 1977. 
Uno, I., Amano, H., Emori, S., Kinoshita, K., Matsui, I., and Sugimoto, N.: Trans-Pacific yellow sand transport observed in April 1998: a numerical simulation, J. Geophys. Res., 106, 18331-18344, 2001.

Uno, I., Harada, K., Satake, S., Hara, Y., and Wang, Z.: Meteorological characteristics and dust distribution of the Tarim Basin simulated by the nesting RAMS/CFORS dust model, J. Meteorol. Soc. Jpn., 83A, 219-239, doi:10.2151/jmsj.83A.219, 2005.

Squires, V. R.: Physics, Mechanics and Processes of Dust and Sandstorms, Adelaide University, Australia, available at: http://www.unccd.int/Lists/SiteDocumentLibrary/Publications/ Global20Alarm20eng.pdf (last access: January 2014), retrieved 29 July, 2007.

Washington, R., Todd, M., Middleton, N. J., and Goudie, A. S.: Dust-storm source areas determined by the total ozone monitoring spectrometer and surface observations, Ann. Assoc. Am. Geogr., 93, 297-313, 2003.

Washington, R., Flamant, C., Parker, D. J., Marsham, J., McQuaid, J. B., Brindley, H., Todd, M., Highwood, E. J., Ryder, C. L., Chaboureau, J. P., Kocha, C., Bechir, M., and Saci, A.: Fennec - The Saharan Climate System, CLIVAR Exchanges, 60, 31-32, 2012.

Watson, A. J., Bakker, D. C. E., Ridgwell, A. J., Boyd, P. W., and Law, C. S.: Effect of iron supply on Southern Ocean $\mathrm{CO}_{2}$ uptake and implications for glacial atmospheric $\mathrm{CO}_{2}$, Nature, 407, 730$733,2000$.

Warner, T. T. and Sheu, R. S.: Multiscale local forcing of the Arabian Desert daytime boundary layer, and implications for the dispersion of surface-released contaminants, J. Appl. Meteorol., 39, 686-707, doi:10.1175/1520-0450-39.5.686, 2000.

Wang, H., Zhang, X. Y., Gong, S. L., Chen, Y., Shi, G. Y., and Li, W.: Radiative feedback of dust aerosols on the East Asian dust storms, J. Geophys. Res., 115, D23214, doi:10.1029/2009JD013430, 2010.

Westphal, D. L., Toon, O. B., and Carlson, T. N.: A two-dimensional investigation of the dynamics and microphysics of Saharan dust storms, J. Geophys. Res., 92, 3027-3049, 1987.
Westphal, D. L., Toon, O. B., and Carson, T. N.: A case study of mobilization and transport of Saharan dust, J. Atmos. Sci., 45, 2145-2175, 1988.

Whiteman, C. D.: Breakup of temperature inversions in deep mountain valleys: Part I. Observations, J. Appl. Meteorol., 21, 270289, 1982.

Wild, O., Zhu, X., and Prather, M. J.: Fast-J: accurate simulation of in- and below cloud photolysis in tropospheric chemical models, J. Atmos. Chem., 37, 245-282, doi:10.1023/A:1006415919030, 2000.

Woodward, S.: Modeling the atmospheric life cycle and radiative impact of mineral dust in the Hadley Centre climate model, J. Geophys. Res., 106, 18155-18166, doi:10.1029/2000JD900795, 2001.

Yue, X., Wang, H., Liao, H., and Fan, K.: Simulation of dust aerosol radiative feedback using the GMOD: 2. Dust-climate interactions, J. Geophys. Res., 115, D04201, doi:10.1029/2009JD012063, 2010.

Zhang, J. and Christopher, S. A.: Longwave radiative forcing of Saharan dust aerosols estimated from MODIS, MISR, and CERES observations on Terra, Geophys. Res. Lett., 30, 2188, doi:10.1029/2003GL018479, 2003.

Zhao, C., Liu, X., Leung, L. R., Johnson, B., McFarlane, S. A., Gustafson Jr., W. I., Fast, J. D., and Easter, R.: The spatial distribution of mineral dust and its shortwave radiative forcing over North Africa: modeling sensitivities to dust emissions and aerosol size treatments, Atmos. Chem. Phys., 10, 8821-8838, doi:10.5194/acp-10-8821-2010, 2010.

Zhu, A., Ramanathan, V., Li, F., and Kim, D.: Dust plumes over the Pacific, Indian, and Atlantic oceans: climatology and radiative impact, J. Geophys. Res., 112, D16208, doi:10.1029/2007JD008427, 2007.

Zhu, X. R., Prospero, J. M., and Millero, F. J.: Daily variability of soluble Fe (II) and soluble total Fe in North African dust in the trade winds at Barbados, J. Geophys. Res., 102, 21297-21305, 1997. 